\title{
Ionic Conduction in Metal-Organic Frameworks with Incorporated Ionic Liquids
}

$\operatorname{AUTHOR}(S)$ :

Yoshida, Yukihiro; Kitagawa, Hiroshi

\section{CITATION:}

Yoshida, Yukihiro ...[et al]. Ionic Conduction in Metal-Organic Frameworks with

Incorporated Ionic Liquids. ACS Sustainable Chemistry and Engineering 2018, 7(1): 70-81

\section{ISSUE DATE:}

2018-01-07

URL:

http://hdl.handle.net/2433/235948

\section{RIGHT:}

This document is the Accepted Manuscript version of a Published Work that appeared in final form in ACS Sustainable Chemistry and Engineering, copyright (c) American Chemical Society after peer review and technical editing by the publisher. To access the final edited and published work see https://doi.org/10.1021/acssuschemeng.8b05552.; The full-text file will be made open to the public on 06 December 2019 in accordance with publisher's 'Terms and Conditions for Self-Archiving'.; この論文は出版社版でありません。引用の際には出版社版をご確認ご利用ください。 This is not the published version. Please cite only the published version. 


\title{
Ionic Conduction in Metal-Organic Frameworks with Incorporated Ionic Liquids
}

\author{
Yukihiro Yoshida*,† and Hiroshi Kitagawa ${ }^{*, \dagger}$
}

$\dagger$ Division of Chemistry, Graduate School of Science, Kyoto University, Kitashirakawa Oiwake-cho, Sakyo-ku, Kyoto 606-8502, Japan

*yoshiday@ssc.kuchem.kyoto-u.ac.jp (YY), kitagawa@kuchem.kyoto-u.ac.jp (HK)

\begin{abstract}
Encapsulation of ionic liquids (ILs) into porous materials can provide environmentally benign solid-state electrolytes for various electrochemical devices. In particular, porous metal-organic frameworks (MOFs) enable to tailor their framework and pore structures by varying central metals and organic linkers, as well as the ILs with an unlimited number of possible cation-anion combinations. Therefore, rational materials design based on the accumulated knowledge about the relationship between materials and functionalities is essential for studying IL@MOF hybrid composites with desired properties. In this review, we first introduce synthetic methodologies to incorporate ILs into MOFs, especially based on post-impregnation approach. Interactions and distribution of component ions of the ILs within the MOFs are discussed from the viewpoint of ion mobility, which is responsible for the performance of electrochemical devices. Finally, we devote attention to the ion-conducting properties, including lithium ion, proton, and hydroxide conductions, of the hybrid composites.
\end{abstract}

Keywords: Ionic liquids, Porous materials, Metal-organic frameworks, Ionic conductivity, Acidity/basicity

\section{Introduction}

Ionic liquids (ILs), which are composed entirely of ions and are in a liquid state at room temperature (RT) or below $100{ }^{\circ} \mathrm{C}$, have been intensively researched in many scientific and industrial areas of synthetic, separation, and electrochemical applications for the past decades. ${ }^{1-5}$ The former property provides extraordinarily high ion density, which results in negligible vapor pressure (i.e., wide liquid temperature region and negligible flammability) and high ionic conductivity. These features open the door to a wide range of applications as environmentally benign alternative to conventional molecular 
solvents for electrochemical devices such as electric double-layer capacitors, ${ }^{6-8}$ fuel cells, ${ }^{9,10}$ dye-sensitized solar cells, ${ }^{11,12}$ and lithium ion batteries. ${ }^{13,14}$ Although ILs have been known for over a century, ${ }^{15,16}$ efforts have only recently been devoted to synthesizing functional ILs, after the discovery of water- and air-stable ILs based on 1-ethyl-3-methylimidazolium (EMI; Figure 1) cations reported in 1992. ${ }^{17,18}$

$* * * * * * * * * *$ Figure 1

Most existing ILs are composed of quaternary heterocyclic monocations such as 1,3-dialkylimidazolium and $N$-alkylpyridinium and small inorganic monoanions such as $\mathrm{BF}_{4}^{-}, \mathrm{PF}_{6}^{-}$, and bis(trifluoromethanesulfonyl)amide (TFSA). In general, cations are responsible for reducing the melting point $\left(T_{\mathrm{m}}\right)$, and therefore, low-symmetrical hetero-cations with well-delocalized charge and/or long alkyl group(s) are utilized. The selection of anions drastically changes various liquid properties such as hydrophilicity/hydrophobicity, miscibility, viscosity, and ionic conductivity. For example, $\mathrm{PF}_{6}$ and TFSA anions introduce hydrophobicity in ILs, ${ }^{19,20}$ whereas MeCOO and $\mathrm{EtOSO}_{3}$ anions stabilize the liquid state down to low temperatures. ${ }^{17,21,22}$ In relation, $\mathrm{Cl}, \mathrm{HCOO}$, and $(\mathrm{MeO})(\mathrm{R}) \mathrm{PO}_{2}(\mathrm{R}=\mathrm{H}, \mathrm{Me}, \mathrm{MeO})$ anions yield ILs that can solubilize cellulose. ${ }^{23-25}$ The use of $\mathrm{BF}_{4}$ and TFSA anions, which yield ILs with a wide electrochemical window, ${ }^{8,19,26}$ and a $\mathrm{F}(\mathrm{HF})_{2.3}$ anion $\left(\mathrm{F}(\mathrm{HF})_{2}{ }^{-}: \mathrm{F}(\mathrm{HF})_{3}{ }^{-}=7: 3\right)$, which yields highly conducting ILs, ${ }^{7,27,28}$ provides the practical way of applying electrolytes to electrochemical devices.

Traditional electrolytes have the limitations of the necessity of using a solvent, unstable operation at high or low temperatures associated with the vaporization or freezing of the solvent, and leakage from the cells owing to its fluidity. As described above, ILs offer significant advantages over liquid electrolytes, especially considering the first two issues, because they involve high-concentrated dissociated cations and anions without a solvent. However, the problem of leakage, which is an important issue for packaging and portability of the devices, still remains. ${ }^{29}$ In addition, their high viscosities ( $>10 \mathrm{mPa}$ ) lead to difficulty in handling during processing.

To overcome these drawbacks, two important approaches have been adopted during the last two decades: dispersion of ILs in solid polymers ${ }^{30,31}$ and polymeric ILs. ${ }^{32,33}$ The latter involves polymerized cations and/or anions (most of them are in a solid state contrary to the name). Compared to the former, the latter shows reduced ionic conductivity due to the presence of immobile ions, but is anticipated to have negligible flammability and high electrochemical durability because of significant interionic 
interactions in highly concentrated ionic media. Single-ion conduction is also available by polymerizing the specific ions. However, in some cases, the serious obstacle is the difficulty of the chemical inclusion of polymerization sites into the precursor ions.

Alternatively, the incorporation of ILs into porous materials is emerging as a topic of research because of their promising applications in "solvent-free" devices capable of preventing liquid leakage. Since the first study of the incorporation of an IL into a porous material reported in 2000, which was carried out by the sol-gel reaction of tetramethylorthosilicate including (EMI)(TFSA), ${ }^{34}$ in-situ incorporation methods including ionothermal ${ }^{35,36}$ and electrochemical ${ }^{37}$ methods have been extended to show wide-ranging and general applicabilities. ${ }^{38-42}$ Ionothermal synthesis is considered as a form of solvothermal synthesis, in which ILs are utilized as a reaction solvent. However, until recently, ILs have served only as a template ${ }^{43,44}$ or only one of the ionic species has been incorporated into the resultant pores. ${ }^{45,46}$ In 2015, the incorporation of (BMI)(TFSA) (BMI: 1-n-butyl-3-methylimidazolium cation) into ZIF-8 [Zn(2-methylimidazolate) 2 (Figure 2$)^{47}$ was succeeded by the ionothermal method using $\mathrm{Zn}\left(\mathrm{NO}_{3}\right)_{2} \cdot 6 \mathrm{H}_{2} \mathrm{O}$, 2-methylimidazole, and (BMI)(TFSA). ${ }^{48}{ }^{1} \mathrm{H} \quad \mathrm{NMR}$ measurements revealed that the molar ratio of the hybrid composite is $[(\mathrm{BMI})(\mathrm{TFSA})] /[\mathrm{ZIF}-8]=0.235$. It remains of interest to challenge this method in obtaining IL-incorporated porous materials, because ionothermally synthesized porous materials usually have charged frameworks and thus only the oppositely charged ions are accommodated in the pores.

$* * * * * * * * * *$ Figure $2 * * * * * * * * * *$

More recently, the post-impregnation approach, in which ILs are incorporated into porous materials after the construction of the framework, has become a growing research area, ${ }^{38-42}$ because a vast number of existing ILs and porous materials can be utilized as they are. It seems that such an impregnation requires less compatibility between ILs and porous materials. So far, three types of strategies have been successfully implemented for the incorporation of ILs into porous materials: (1) wet impregnation, (2) capillary action, and (3) tandem procedures, as shown in Figure 3. Procedure (1) is usually performed by the dispersion of porous solids in a solution including ILs, whereas procedure (2) involves the mixing process of stoichiometric amounts of an IL and a porous solid using a mortar followed by annealing to ensure better dispersion of the IL into the pores. In procedure (3), the precursors of an IL are incorporated into the pores followed by the reaction (e.g., heating) to give an IL trapped 
inside the pores. It is intuitively reasonable that this procedure is favorable for incorporating ILs composed of bulky ions and the ions are confined within the pores when the pore aperture is narrower than the size of the post-synthesized ions. For this reason, this procedure is also called the "ship-in-bottle" method.

$* * * * * * * * * *$ Figure $3 * * * * * * * * * *$

In this review, we present the interactions with frameworks and/or counter ions and the distribution of ions that constitute ILs in host porous media, while comparing to those in the bulk state to gain a deeper understanding of how the confinement affects the ion diffusion performance. After that, hybrid composites, for which the ion-conducting properties are investigated, are introduced according to the material type. As for porous materials, we mainly focus on metal-organic frameworks (MOFs), because diverse combinations of metal-based building blocks and organic linkers allow for tailoring their framework and pore structures, compositions, and functionalities. ${ }^{49-53}$ Interactions with ions of ILs, which are inevitably related to the ion-conducting properties of the hybrid materials, may also be controlled by the selection of both central metals and organic linkers.

\section{Ion-framework and ion-ion interactions}

This assessment is particularly important for designing IL@MOF hybrid composites with desired functionalities, although there is an interplay of multiple types of interactions between ions of ILs and frameworks such as Coulombic, hydrogen bonding, van der Waals, and $\pi-\pi$ interactions. From molecular dynamics (MD) simulations, bulky cations, such as BMI, are preferentially distributed around the open pore close to organic linkers because of the configuration entropy effect, whereas small anions, such as $\mathrm{SCN}^{-}, \mathrm{BF}_{4}^{-}$, and $\mathrm{PF}_{6}^{-}$, tend to connect with cationic metal clusters (Figure 4). ${ }^{54-56}$ The increase in the anion size, such as TFSA, results in depressed interactions with metal clusters, and interionic interactions with counter cations become significant to form an ion-pair. ${ }^{55,57}$ Although the calculated binding energy between the TFSA anion with $\mathrm{CO}_{2}\left(28.42 \mathrm{~kJ} \mathrm{~mol}^{-1}\right)$ is higher than that in the case of the $\mathrm{PF}_{6}$ anion $\left(25.11 \mathrm{~kJ} \mathrm{~mol}^{-}\right.$ ${ }^{1}$ ), the selectivity of a $\mathrm{CO}_{2} / \mathrm{N}_{2}$ mixture for (BMI)(TFSA)@MOF-5 (MOF-5 or IRMOF-1: $\mathrm{Zn}_{4} \mathrm{O}(\mathrm{bdc})_{3}$, where bdc $^{2-}$ stands for benzene-1,4-dicarboxylate ${ }^{58}$ ) is less than that for $(\mathrm{BMI})\left(\mathrm{PF}_{6}\right) @ \mathrm{MOF}-5 .^{55}$ The formation of BMI-TFSA ion-pairs, in which an amide nitrogen and sulfonyl oxygens of TFSA would interact with an imidazolium ring of BMI through the hydrogen bonds, ${ }^{59}$ in MOFs, appears to disturb the $\mathrm{CO}_{2}$ adsorption 
in the hybrid composite.

$* * * * * * * * * *$ Figure $4 * * * * * * * * * *$

It has been well established that the empirical Walden rule, namely, that the molar conductivity estimated from the electrochemical impedance measurements $\left(\Lambda_{\mathrm{imp}}\right)$ is inversely proportional to the viscosity $(\eta)$ of the liquid ${ }^{60}$ based on a variety of aqueous solutions, can be applied to ILs. ${ }^{61,62}$ According to the rule, the discrepancy from the Walden product, $\Lambda_{\mathrm{imp}} \eta$, of an infinitely diluted $\mathrm{KCl}$ aqueous solution $\left(10^{2} \mathrm{~S} \mathrm{~cm} \mathrm{cma} \mathrm{s}^{2}\right.$ $\mathrm{mol}^{-1}$ ), in which the component ions with nearly equal ion sizes are completely dissociated, indicates the presence of a significant fraction of ion-pairs composed of oppositely charged ions. The $\Lambda_{\mathrm{imp}} \eta$ value can be substituted for the ratio, $\Lambda_{\mathrm{imp}} / \Lambda_{\mathrm{NMR}}$, where $\Lambda_{\mathrm{NMR}}$ is the molar conductivity numerically calculated from the pulsed-field gradient spin-echo NMR diffusion coefficients of cations and anions in ILs. The order for $\Lambda_{\mathrm{imp}} / \Lambda_{\mathrm{NMR}},(\mathrm{BMI})\left(\mathrm{PF}_{6}\right)(0.68)>(\mathrm{BMI})(\mathrm{TFSA})(0.61),{ }^{62}$ indicates that the degree of ion-pairing in the bulk is more pronounced in (BMI)(TFSA) than that in (BMI)( $\left.\mathrm{PF}_{6}\right)$ as in the case of IL@MOF-5 hybrid composites. ${ }^{55}$ Generally, the combination of a strongly Lewis-acidic cation and a strongly Lewis-basic anion yields a salt with a high $T_{\mathrm{m}}$ (e.g., $\mathrm{NaCl}$ ) owing to interionic Coulombic interactions, whereas the reduction of Lewis basicity of anions results in depressed interionic interactions, i.e., increased ion dissociation in ILs (Figure 5). Thus, it is most likely that the utilization of weakly Lewis-acidic cations such as $N, N$-dialkylpyrrolidinium and $N, N$-dialkylpiperidinium (see Figure 1) modifies the permeation and sorption selectivities that exceed Robeson's upper bound. ${ }^{63}$

$* * * * * * * * * *$ Figure $5 * * * * * * * * * *$

\section{Ion distribution and diffusivity}

In MD simulations of a realistic model of nanoporous hydroxylated silica with a diameter of $4.8 \mathrm{~nm}$, in which oxygen dangling bonds are saturated by hydrogen atoms, the distribution of (BMI)(TFSA) varies largely depending on its volumetric occupancy $(f)$ in the pores (Figure 6). ${ }^{64}$ For $f=0.25$, a layer composed of cations and anions is constructed at the silica surface, whereas a cation-anion pair layer is deposited on the layer and gradually occupies in the center of the pore for $f=0.5$. For $f=1.0$, the whole pore accommodates the ions, which comprises seven cationic layers and six anionic layers. Such a density oscillation remains marked in nanoporous hydroxylated silica 
with a diameter of as small as $2.0 \mathrm{~nm}$, which accommodates four cationic layers and three anionic layers. ${ }^{65}$ Regardless of the diameter, the first cationic layer is the closest to the wall and the first anionic layer is formed between the first and second cationic layers. The oscillatory structure becomes less pronounced towards the center of the cell owing to the depression of the Coulombic interactions with the silica surface.

\section{$* * * * * * * * * *$ Figure $6 * * * * * * * * * *$}

Ion diffusion in the $4.8 \mathrm{~nm}$-silica for $f=0.25$ is largely suppressed because most of the incorporated ions strongly interact with the silica surface. ${ }^{64}$ As the $f$ value increases, the ion diffusion becomes faster and recovers its bulk properties. Despite the ordering of the IL at the surface, the IL shows only a short-range ordered structure as expected for a liquid-like state. Nonetheless, ion diffusions of both ions fall below one-quarter of those of the bulk even for $f=1$. The calculated diffusivity of BMI cations $\left(8.2 \times 10^{-8} \mathrm{~cm}^{2} \mathrm{~s}^{-1}\right.$ for $f=1)$ is apparently higher than that of TFSA anions $\left(5.0 \times 10^{-8} \mathrm{~cm}^{2} \mathrm{~s}^{-1}\right.$ for $\left.f=1\right)$, as in the case of the bulk IL estimated from pulsed-field gradient spin-echo NMR measurements. ${ }^{66,67}$

A computational study of the filling effect of an IL in MOF-5 on the ion mobility has been reported, where $(\mathrm{BMI})\left(\mathrm{PF}_{6}\right)$ occupies in MOF-5 with different weight ratios of $(\mathrm{BMI})\left(\mathrm{PF}_{6}\right) / \mathrm{MOF}-5=0.4-1.5 .^{54}$ The mobilities of both $\mathrm{BMI}$ cations and $\mathrm{PF}_{6}$ anions in the pores, which are estimated based on mean-squared displacement, are less than those in the bulk, because BMI cations and $\mathrm{PF}_{6}$ anions interact with phenyl rings of bde ${ }^{2-}$ and metal clusters, respectively, in the pores, as described above. A higher mobility of BMI cations than that of $\mathrm{PF}_{6}$ anions is consistent with the experimental results. ${ }^{66,68}$

A narrow aperture in MOFs may obstruct the transportation of ions between cavities, resulting in the confinement of the ions within the cavities as in the case of hybrid composites obtained by the ship-in-bottle method. Very recently, a lithium-containing IL, $\mathrm{Li}_{0.2} \mathrm{EMI}_{0.8} \mathrm{TFSA}$, was incorporated into MOF-525(Cu $)^{69}$ using the capillary action method, ${ }^{70}$ in which $\mathrm{Zr}_{6} \mathrm{O}_{4}(\mathrm{OH})_{4}{ }^{12+}$ cluster cores connect with each other through $\mathrm{Cu}(\mathrm{II})$-porphyrin molecules as a linker (Figure 7). The transference number of $\mathrm{Li}^{+}\left(t_{\mathrm{Li}+}\right)$ cations, which was estimated on the basis of the Evans method, in MOF-525(Cu) $(0.36)$ is apparently higher than that for the bulk (0.14). The increase in $t_{\mathrm{Li}+}$ may arise from the confinement of bulky EMI and TFSA cations within the pores because the aperture size $\left(1.2 \times 0.7 \mathrm{~nm}^{2}\right)$ is comparable to their ion sizes. 


\section{Ion-conduction in IL@MOF hybrid composites}

Ion-conducting MOFs incorporating ILs have increasingly attracted attention as potentially benign solvents for electrochemical devices. At the present stage, however, the utilization of MOFs remains severely limited; ZIF-8, ${ }^{47}$ UiO-67(Zr) $\left(\mathrm{Zr}_{6} \mathrm{O}_{4}(\mathrm{OH})_{4}(\mathrm{bpdc})_{6}\right.$, where bpdc stands for 4,4'-biphenyldicarboxylate $),{ }^{71}$ and MIL-101(Cr) $\left(\mathrm{Cr}_{3} \mathrm{O}(\mathrm{F}, \mathrm{OH})\left(\mathrm{H}_{2} \mathrm{O}\right)_{2}(\mathrm{bdc})_{3}\right)^{72}$ have been mainly targeted. For MOFs, primary factors that are vital to the success of the synthesis of IL@MOF hybrid materials via the post-impregnation approach are the insolubility in ILs, unreactivity with ILs, and inclusion of pores and apertures that are large enough to accommodate ILs, where "ILs" corresponds to "precursors of ILs" in the case of the ship-in-bottle method. MOFs that have a high tolerance to acid or base are necessary to yield hybrid composites incorporating liquid acid or base. In the following, we introduce the ion-conducting properties for each category classified by the types of ILs and/or MOFs (Table 1). Hereinafter, the capillary action method is utilized unless otherwise stated.

IL@ZIF-8. (EMI)(TFSA) (ionic conductivity $\sigma=8.4 \times 10^{-3} \mathrm{~S} \mathrm{~cm}^{-1}$ at $20^{\circ} \mathrm{C}^{19}$ ) with different volumetric occupancies $(f=0.25-1)$ was incorporated into ZIF-8. ${ }^{73,74}$ The impregnation was experimentally confirmed on the basis of the reduction of a low-angle peak in the powder X-ray diffraction pattern, reduction of nitrogen gas adsorption, and disappearance of melting/freezing peaks in the DSC profile. In the hybrid composites, the liquid state of (EMI)(TFSA) is more stable compared to bulk (EMI)(TFSA) $\left(T_{\mathrm{m}}=-\right.$ $16{ }^{\circ} \mathrm{C}$ ); notably, it appears that the manner of change in thermal behavior of ILs by the incorporation into porous materials has no simple correlation with the types of ILs and porous materials. ${ }^{29,41}$ A combination of the Rietveld refinement and maximum entropy methods to the diffraction pattern also supports the impregnation. Ionic conductivity steadily increases with the $f$ value, but the $\sigma$ value even for $f=1\left(2.6 \times 10^{-5} \mathrm{~S} \mathrm{~cm}^{-1}\right.$ at $22{ }^{\circ} \mathrm{C}$ ) is about two orders of magnitude less than that of bulk (EMI)(TFSA) at RT. However, the conductivity of the hybrid composite with $f=1$ below the melting temperature of bulk (EMI)(TFSA) is higher than that of the bulk, as shown in Figure 8. This feature makes it particularly useful as electrolytes for electrochemical devices that operate in the low-temperature region. Another example of IL@ZIF-8, namely, ionothermally synthesized cholinium hydroxide@ZIF-8 hybrid composite (melting point of cholinium hydroxide is unknown), has a much lower $\sigma$ value of $4 \times 10^{-7} \mathrm{~S} \mathrm{~cm}^{-1}$ at $25^{\circ} \mathrm{C}$ in $98 \% \mathrm{RH}^{75}$

$* * * * * * * * * *$ Figure $8 * * * * * * * * * *$ 
A lithium-containing IL, $\mathrm{Li}_{0.2} \mathrm{EMI}_{0.8} \mathrm{TFSA}$, was also incorporated into ZIF-8 with the prospect of the applications as solid-state electrolytes for lithium-ion batteries. ${ }^{76}$ The ion diffusivity of $\mathrm{Li}^{+}$cations in $\mathrm{Li}_{0.2} \mathrm{EMI}_{0.8} \mathrm{TFSA} @ \mathrm{ZIF}-8$ with $f=1$, which was estimated from ${ }^{7} \mathrm{Li}$ pulsed-field gradient spin-echo NMR measurements, is about two orders of magnitude less than that of bulk $\mathrm{Li}_{0.2} \mathrm{EMI}_{0.8} \mathrm{TFSA}$ (Figure 9). Because the pore aperture $(0.34 \mathrm{~nm})$ is large enough that bare $\mathrm{Li}^{+}$cations pass through to contribute to the ionic conductivity, the formation of ion clusters, such as $\left[\operatorname{Li}(\mathrm{TFSA})_{2}\right]^{-}$(refs 77,78), may suppress the $\mathrm{Li}^{+}$ion conduction. It seems that this hypothesis conflicts with the finding in ref 70, in which the transference number of $\mathrm{Li}^{+}$cations in $\mathrm{Li}_{0.2} \mathrm{EMI}_{0.8} \mathrm{TFSA}$ is increased by the incorporation into MOF-525(Cu). Although the data are insufficient at present to make a comparison, this discrepancy may be associated with the difference in the dimension of the pore apertures between ZIF-8 (Figure 2) ${ }^{47}$ and MOF-525(Cu) (Figure 7). ${ }^{69}$

$* * * * * * * * * *$ Figure $9 * * * * * * * * * *$

IL@UiO-67(Zr). Crystalline (EMI)Cl $\left(T_{\mathrm{m}}=78{ }^{\circ} \mathrm{C}\right)$ was incorporated into UiO-67( $\mathrm{Zr})$ by heating the mixture at $130{ }^{\circ} \mathrm{C}$ to disperse the melt $(\mathrm{EMI}) \mathrm{Cl}$ in the pores. ${ }^{79}$ The $\sigma$ value of the hybrid composite with a molar ratio of $[(\mathrm{EMI}) \mathrm{Cl}] /[\mathrm{UiO}-67(\mathrm{Zr})]=7.8$ is $1.5 \times 10^{-4} \mathrm{~S} \mathrm{~cm}^{-1}$ at $100{ }^{\circ} \mathrm{C}$ and attains $1.7 \times 10^{-3} \mathrm{~S}$ $\mathrm{cm}^{-1}$ at $200{ }^{\circ} \mathrm{C}$ on heating with an activation energy $\left(E_{\mathrm{a}}\right)$ of $0.37 \mathrm{eV}$. It is possible that the observed low conductivity is associated with significant interactions of chloride anions with EMI cations and/or cationic metal clusters. Very recently, a lithium-containing IL, $\mathrm{Li}_{0.17} \mathrm{EMI}_{0.83}$ TFSA, was incorporated into the UiO-67(Zr), with different loading levels; namely, $0.5-1.5 \mathrm{~mL}$ of $\mathrm{Li}_{0.17} \mathrm{EMI}_{0.83} \mathrm{TFSA}$ per gram of UiO-67(Zr). ${ }^{80}$ The $\sigma$ value at $30{ }^{\circ} \mathrm{C}$ increases with the loading level, from $1.5 \times 10^{-5} \mathrm{~S}$ $\mathrm{cm}^{-1}$ for $0.5 \mathrm{~mL}$ to $3.1 \times 10^{-4} \mathrm{~S} \mathrm{~cm}^{-1}$ for $1.5 \mathrm{~mL}$. It should be noted that this value is one of the highest RT conductivities among those of IL-incorporated MOF hybrid composites.

Liquid acid@MIL-101(Cr). Impregnation of liquid Brønsted acids, sulfuric acid $\left(\mathrm{H}_{2} \mathrm{SO}_{4} ; \mathrm{p} K_{\mathrm{a}}=-3.0\right)$ and phosphoric acid $\left(\mathrm{H}_{3} \mathrm{PO}_{4} ; \mathrm{p} K_{\mathrm{a}}=2.1\right)$, into acid-tolerant MIL-101(Cr) was performed by mixing in an aqueous solution (i.e., wet impregnation method). ${ }^{81}$ The $f$ values were estimated to be approximately 0.7 and 0.8 , respectively, from the elemental analysis, and the acids can be rapidly removed by washing with water. The temperature dependence of ionic conductivity of $\mathrm{H}_{2} \mathrm{SO}_{4} @ \mathrm{MIL}-101(\mathrm{Cr})$, 
which was estimated to be $4.0 \times 10^{-2} \mathrm{~S} \mathrm{~cm}^{-1}$ at approximately $50{ }^{\circ} \mathrm{C}$ in $0.6 \mathrm{~mol} \%$ water $(=20 \%$ relative humidity $(\mathrm{RH}))$, exhibits a broad maximum at around $80{ }^{\circ} \mathrm{C}\left(6.0 \times 10^{-2}\right.$ $\mathrm{S} \mathrm{cm}^{-1}$ ) followed by a gradual decrease on further heating possibly due to the loss of water molecules. On the other hand, the $\sigma$ value of $\mathrm{H}_{3} \mathrm{PO}_{4} @ \mathrm{MIL}-101(\mathrm{Cr})$ is $2.5 \times 10^{-4} \mathrm{~S}$ $\mathrm{cm}^{-1}$ at around $50{ }^{\circ} \mathrm{C}$ and follows the Arrhenius law with $E_{\mathrm{a}}=0.25 \mathrm{eV}$ to attain $\sigma=3 \times$ $10^{-3} \mathrm{~S} \mathrm{~cm}^{-1}$ at $150{ }^{\circ} \mathrm{C}$. The $E_{\mathrm{a}}$ value is comparable to that of Nafion $\left(0.22 \mathrm{eV}^{82}\right)$, and therefore, the Grotthuss mechanism ${ }^{51,83}$ is responsible for proton conduction in the hybrid composite. Such solid-state proton conductors could serve as fuel cell electrolytes under entirely anhydrous conditions at high temperatures.

Subsequently, liquid trifluoromethanesulfonic acid $\left(\mathrm{TfOH} ; \mathrm{p} K_{\mathrm{a}}(\right.$ in $\left.\mathrm{MeCN})=2.6\right)$ and solid $p$-toluenesulfonic acid $\left(\mathrm{TsOH} ; \mathrm{p} K_{\mathrm{a}}=-2.8, T_{\mathrm{m}}=106-107{ }^{\circ} \mathrm{C}\right)$ were incorporated into MIL-101(Cr) using the same procedure. ${ }^{84}$ Whereas TsOH@MIL-101(Cr) is less conductive due to the bulky $\pi$-conjugated structure of the acid (less than $10^{-7} \mathrm{~S} \mathrm{~cm}^{-1}$ even above $100{ }^{\circ} \mathrm{C}$ in 0.6 mol\% water), the $\sigma$ value of TfOH@MIL-101(Cr) is as high as $5 \times 10^{-2} \mathrm{~S} \mathrm{~cm}^{-1}$ at approximately $60{ }^{\circ} \mathrm{C}$ in $0.6 \mathrm{~mol} \%$ water and follows the Arrhenius law with $E_{\mathrm{a}}=0.23 \mathrm{eV}$. As in the case of $\mathrm{H}_{3} \mathrm{PO}_{4} @ \mathrm{MIL}-101(\mathrm{Cr}),{ }^{81}$ the proton mobility appears to be dominantly governed by the Grotthuss mechanism.

Binary IL@MIL-101(Cr). Recently, a mixture of zwitterionic liquid (EIMS; p $K_{\mathrm{a}}$ 6.8 for the protonated form) and acid HTFSA $\left(\mathrm{p} K_{\mathrm{a}} \sim 2\right)$ with a molar ratio of 3:2, which serves as a Brønsted acid-base buffer (Figure 10), was impregnated into MIL-101(Cr) with different volumetric occupancies $(f=0.25-1) .{ }^{85}$ In the binary EIMS-HTFSA mixture, protonated $-\mathrm{SO}_{3} \mathrm{H} / \mathrm{HTFSA}$ and unprotonated $-\mathrm{SO}_{3}{ }^{-} / \mathrm{TFSA}^{-}$matrices serve as proton-donating and proton-accepting sites, respectively, which could modify the proton mobility in the favorable direction of hopping between the negatively charged sites $\left(-\mathrm{SO}_{3}{ }^{-} / \mathrm{TFSA}^{-}\right)$. However, the hybrid composite with $f=1$ is much less conductive $(2.0$ $\times 10^{-4} \mathrm{~S} \mathrm{~cm}^{-1}$ at $140{ }^{\circ} \mathrm{C}$ ) and shows a sizable $E_{\mathrm{a}}$ of $0.76 \mathrm{eV}$ exceeding that expected from the Grotthuss mechanism $(0.1-0.4 \mathrm{eV})$. In general, the rate-limiting step of the Grotthuss-type proton mobility is regarded as a structural reorientation of the proton carrier, and therefore, bulky EIMS molecules may give rise to the enhanced $E_{\text {a }}$ value in the Grotthuss mechanism. ${ }^{85}$

$* * * * * * * * * *$ Figure 10

Very recently, three types of Brønsted acid-base buffers, in which zwitterionic EIMS was combined with different sulfonic acid derivatives, $\mathrm{H}_{2} \mathrm{SO}_{4} \quad\left(\mathrm{p} K_{\mathrm{a}}=-3.0\right)$, methanesulfonic acid $\left(\mathrm{MeSO}_{3} \mathrm{H} ; \mathrm{p} K_{\mathrm{a}}=-2.6\right)$, and $\mathrm{TsOH}\left(\mathrm{p} K_{\mathrm{a}}=-2.8\right)$, were incorporated 
into MIL-101(Cr). ${ }^{86}$ The $\sigma$ value of EIMS-H ${ }_{2} \mathrm{SO}_{4} @ \mathrm{MIL}-101(\mathrm{Cr})$ with $f=1$ was estimated to be $2.5 \times 10^{-4} \mathrm{~S} \mathrm{~cm}^{-1}$ at $50{ }^{\circ} \mathrm{C}$ and $1.9 \times 10^{-3} \mathrm{~S} \mathrm{~cm}^{-1}$ at $150{ }^{\circ} \mathrm{C}$. Although the absolute value is much lower than that of $\mathrm{H}_{2} \mathrm{SO}_{4} @ \mathrm{MIL}-101(\mathrm{Cr}),{ }^{81}$ the temperature dependence follows the Arrhenius law unlike $\mathrm{H}_{2} \mathrm{SO}_{4} @ \mathrm{MIL}-101(\mathrm{Cr})$ and the $E_{\mathrm{a}}$ value $(0.26 \mathrm{eV})$ is lower than that of bulk EIMS- $\mathrm{H}_{2} \mathrm{SO}_{4}(0.33 \mathrm{eV})$. The discernible difference in $\sigma, \quad$ EIMS-H $\mathrm{SO}_{4} @ M I L-101(\mathrm{Cr})>$ EIMS-MeSO $3 \mathrm{H} @$ MIL-101(Cr) > EIMS-TsOH@MIL-101(Cr), strongly suggests that the proton mobility is rather under the control of the size of acids than their acidity. The fact that the hybrid composite including larger acids has higher $E_{\mathrm{a}}$ must be a reflection of the importance of the reorientational motion in determining the proton mobility in the Grotthuss mechanism. The possible difference in interfacial miscibility between aromatic $\mathrm{bdc}^{2-}$ in the framework and acids also may be a part of the reason.

Liquid base@MOFs. To the best of our knowledge, the first example of base-incorporated MOFs, in which counter cations of hydroxide ions provided several ILs, is the cholinium hydroxide@ZIF-8 hybrid composite as described above. ${ }^{75}$ Recently, the incorporation of 1-ethyl-3-vinylimidazolium (EVI) hydroxide into FJU-66 (FJU-66: $\quad \mathrm{Cu}_{6}(\mathrm{NDI})_{3} \cdot 2 \mathrm{DMF} \cdot 6 \mathrm{MeOH} \cdot 2 \mathrm{H}_{2} \mathrm{O}$, where $\mathrm{H}_{2} \mathrm{NDI}$ stands for 2,7-bis(3,5-dimethyl)dipyrazol-1,4,5,8-naphthalene-tetracarboxydiimide) was performed by the wet impregnation in an EtOH solution, ${ }^{87}$ although the melting point of (EVI)OH is unknown. Under $95 \% \mathrm{RH}$, the hybrid composite was reported to show a high ionic conductivity $\left(5.2 \times 10^{-2} \mathrm{~S} \mathrm{~cm}^{-1}\right.$ at $\left.20{ }^{\circ} \mathrm{C}\right)$, mainly arising from the diffusion of hydroxide ions through water-mediated networks within the pores. Such hydroxide conductors have gained increasing interest as electrolyte membranes for alkaline anion exchange membrane fuel cells, which use non-precious metal catalysts instead of platinum for oxygen reduction. ${ }^{8}$ In particular, hydroxide-conducting IL@MOF hybrid composites are good candidates for solid-state electrolytes for diverse electrochemical devices that can operate at low temperatures, because the liquid state of ILs in IL@MOF hybrid composites is expected to be stable down to low temperatures owing to the confinement effect. There are reports of hydroxide-conducting polymers containing hybrid composites that can be categorized in this section (see below).

IL@MOF dispersed in polymer. There are several ion-conducting films containing IL@MOF hybrid composites. ${ }^{75,89,90}$ A film with a thickness of 30-40 $\mu \mathrm{m}$ was fabricated by drop casting of a MeCN solution of (BMI)Br@MOF-199 ((BMI)Br: $T_{\mathrm{m}}=78{ }^{\circ} \mathrm{C}$; MOF-199 or HKUST-1: $\mathrm{Cu}_{3}(\mathrm{btc})_{2}$, where $\mathrm{btc}^{3-}$ stands for benzene-1,3,5-tricarboxylate ${ }^{91}$ ) with $f=0.5$ and poly(ethylene oxide). ${ }^{89}$ It should be noted that the ionic conductivity of the film is very high $\left(1.3 \times 10^{-3} \mathrm{~S} \mathrm{~cm}^{-1}\right)$ at RT, 
despite including less mobile bromide anions.

Precursors of polymeric ILs, namely, $N$-vinylimidazole and 4-vinylbenzyl chloride, were impregnated into MIL-101(Cr), and subsequently, the hybrid composite was heated at $60 \quad{ }^{\circ} \mathrm{C}$ for promoting the polymerization of 1-ethenyl-3-[(4-ethenylphenyl)methyl]imidazolium chloride to give a cross-linked polycationic IL (PIL in Figure 11 and also see Figure 1). ${ }^{90}$ This procedure reminds us of the ship-in-bottle method as mentioned above. Dispersing of PIL@MIL-101(Cr) in a tetrahydrofuran solution of styrene-ethylene/butylene-styrene (SEBS) block copolymers followed by the pressing the dried composite provides the film with a thickness of approximately $270 \mu \mathrm{m}$. This film was soaked in an aqueous $\mathrm{NaOH}$ solution to exchange $\mathrm{Cl}^{-}$for $\mathrm{OH}^{-}$. The hydroxide conductivity of the film was estimated to be $3.7 \times 10^{-2} \mathrm{~S}$ $\mathrm{cm}^{-1}$ at $20{ }^{\circ} \mathrm{C}$, which is markedly higher than that of the cholinium hydroxide@ZIF-8 hybrid composite dispersed in poly(vinyl alcohol) $\left(1.1 \times 10^{-4} \mathrm{~S} \mathrm{~cm}^{-1}\right.$ at $25{ }^{\circ} \mathrm{C}$ in $33 \%$ $\mathrm{RH}){ }^{75}$

$* * * * * * * * * *$ Figure 11

Formation of ion-pairs composed of oppositely charged ions reduces the ionic conductivity, as mentioned above. The deviation from the Walden product, which is a diagnostic for the ion-pair formation, is more pronounced for ILs composed of strongly Lewis-acidic cations such as 1-alkyl-3-methylimidazolium. Furthermore, an elongated alkyl or perfluoroalkyl group in cations ${ }^{92-94}$ or anions ${ }^{95,96}$ also has a tendency to reduce the Walden product, although it may be contributed from the different mobilities between cations and anions. In the case of protic ILs, ${ }^{97-99}$ the difference in aqueous $\mathrm{p} K_{\mathrm{a}}$ between the conjugate acid of the base and the acid $\left(\Delta \mathrm{p} K_{\mathrm{a}}\right.$; for example, the combination of $n$-propylamine ( $\mathrm{p} K_{\mathrm{a}}=10.57$ for $n$-propylammonium cation) and formic acid $\left(\mathrm{p} K_{\mathrm{a}}=3.75\right)$ gives $\left.\Delta \mathrm{p} K_{\mathrm{a}}=6.82\right)$ is used as a measure of the degree of proton transfer that is responsible for the ionicity of ILs. ${ }^{97,100}$ A large $\Delta \mathrm{p} K_{\mathrm{a}}$ value resulting in a complete proton transfer between the component acid and base gives a more ideal IL, which has a nearly ideal Walden product and thus highly ionic conductivity. On the other hand, the combination of an acid and a base with comparable $\mathrm{p} K_{\mathrm{a}}$ values only gives a nearly neutral "mixture" with no contribution to ionic conductivity. However, the possible existence of labile protons may lead to high proton mobility through deprotonated acids and the bases. ${ }^{100-102}$ It is most likely that the same can be applied to hydroxide conductors; namely, a careful choice of acid-base combination in terms of $\mathrm{p} K_{\mathrm{a}}$ can yield highly hydroxide-conducting ILs associated with labile hydroxide anions. 


\section{Concluding remarks}

The post-synthetic approach has a great advantage for obtaining IL@MOF hybrid composites with desired properties, because individually well-established ILs and MOFs can be utilized as starting materials in this approach. However, both ILs and MOFs so far employed for obtaining IL@MOF hybrid composites remain very limited in number, which clearly indicates that this synthetic strategy is at a primitive level of development. To explore new and more versatile hybrid composites, there is a great scope to extend the range of choices of ILs and MOFs. For example, the introduction of hydrophilic/hydrophobic functional groups into cations of ILs and/or organic linkers of MOFs will exert a great impact on the ion diffusion (including proton and hydroxide diffusions), as a consequence of the modified interactions and distribution of ions in the MOFs. In relation, experimental demonstration of ion distribution within MOFs may provide a significant step forward in understanding the key factors that determine the ion diffusion. Apart from the ion-conducting properties mainly introduced in this review, current potential applications, such as catalysis, gas storage, and gas separation performance with a reduced environmental load, must also require the newly gained knowledge to bring about drastic developments in the related fields. It is safe to assume that the exploration of better combinations will provide more sophisticated hybrid composites, which might surpass both parent materials, ILs and MOFs.

\section{References}

(1) Wasserscheid, P., Welton T., Eds. Ionic Liquids in Synthesis; Wiley-VCH: Weinheim, 2003.

(2) Wasserscheid, P.; Keim, W. Ionic liquids -new "solutions" for transition metal catalysis. Angew. Chem. Int. Ed. 2000, 39, 3772-3789.

(3) Davis, Jr, J. H. Task-specific ionic liquids. Chem. Lett. 2004, 33, 1072-1077.

(4) Fei, Z.; Geldbach, T. J.; Zhao, D.; Dyson, P. J. From dysfunction to bis-function: on the design and applications of functionalised ionic liquids. Chem. Eur. J. 2006, 12, 2122-2130.

(5) Yoshida, Y.; Saito, G. Design of functional ionic liquids using magneto-and luminescent-active anions. Phys. Chem. Chem. Phys. 2010, 12, 1675-1684.

(6) McEwen, A. B.; Ngo, H. L.; LeCompte, K.; Goldman, J. L. Electrochemical properties of imidazolium salt electrolytes for electrochemical capacitor applications. $J$. Electrochem. Soc. 1999, 146, 1687-1695.

(7) Ue, M.; Takeda, M.; Toriumi, A.; Kominato, A.; Hagiwara, R.; Ito, Y. Application of 
low-viscosity ionic liquid to the electrolyte of double-layer capacitors. J. Electrochem. Soc. 2003, 150, A499-A502.

(8) Sato, T.; Masuda, G.; Takagi, K. Electrochemical properties of novel ionic liquids for electric double layer capacitor applications. Electrochim. Acta 2004, 49, 3603-3611. (9) de Souza, R. F.; Padilha, J. C.; Gonçalves, R. S.; Dupont, J. Room temperature dialkylimidazolium ionic liquid-based fuel cells. Electrochem. Commun. 2003, 5, 728731.

(10) Susan, M. A. B. H.; Noda, A.; Mitsushima, S.; Watanabe, M. Brønsted acid-base ionic liquids and their use as new materials for anhydrous proton conductors. Chem. Commun. 2003, 938-939.

(11) Papageorgiou, N.; Athanassov, Y.; Armand, M.; Bonhôte, P.; Pettersson, H.; Azam, A.; Grätzel, M. The performance and stability of ambient temperature molten salts for solar cell applications. J. Electrochem. Soc. 1996, 143, 3099-3108.

(12) Wang, P.; Zakeeruddin, S. M.; Comte, P.; Exnar, I.; Grätzel, M. Gelation of ionic liquid-based electrolytes with silica nanoparticles for quasi-solid-state dye-sensitized solar cells. J. Am. Chem. Soc. 2003, 125, 1166-1167.

(13) Armand, M.; Endres, F.; MacFarlane, D. R.; Ohno, H.; Scrosati, B. Ionic-liquid materials for the electrochemical challenges of the future. Nat. Mater. 2009, 8, 621-629. (14) Lewandowski, A.; Świderska-Mocek, A. Ionic liquids as electrolytes for Li-ion batteries -an overview of electrochemical studies. J. Power Sources 2009, 194, 601609.

(15) Gabriel, S.; Weiner, J. Ueber einige Abkömmlinge des Propylamins. Ber. 1888, 21, 2669-2679.

(16) Walden, P. Molecular weights and electrical conductivity of several fused salts. Bull. Acad. Imper. Sci. (St. Petersburg) 1914, 8, 405-422.

(17) Wilkes, J. S.; Zaworotko, M. J. Air and water stable 1-ethyl-3-methylimidazolium based ionic liquids. J. Chem. Soc., Chem. Commun. 1992, 965-966.

(18) Cooper, E. I.; O’Sullivan, E. J. M. Proc. -Electrochem. Soc. 1992, 92-16, 386396.

(19) Bonhôte, P.; Dias, A.-P.; Armand, M.; Papageorgiou, N.; Kalyanasundaram, K.; Grätzel, M. Hydrophobic, Highly Conductive Ambient-Temperature Molten Salts. Inorg. Chem. 1996, 35, 1168-1178.

(20) Suarez, P. A. Z.; Einloft, S.; Dullius, J. E. L.; de Souza, R. F.; Dupont, J. Synthesis and physical-chemical properties of ionic liquids based on 1-n-butyl-3-methylimidazolium cation. J. Chim. Phys. Phys.-Chim. Biol. 1998, 95, 1626-1639. 
(21) Holbrey, J. D.; Reichert, W. M.; Swatloski, R. P.; Broker, G. A.; Pitner, W. R.; Seddon, K. R.; Rogers, R. D. Efficient, halide free synthesis of new, low cost ionic liquids: 1,3-dialkylimidazolium salts containing methyl- and ethyl-sulfate anions. Green Chem. 2002, 4, 407-413.

(22) Borra, E. F.; Seddiki, O.; Angel, R.; Eisenstein, D.; Hickson, P.; Seddon, K. R.; Worden, S. P. Deposition of metal films on an ionic liquid as a basis for a lunar telescope. Nature 2007, 447, 979-981.

(23) Swatloski, R. P.; Spear, S. K.; Holbrey, J. D.; Rogers, R. D. Dissolution of cellose with ionic liquids. J. Am. Chem. Soc. 2002, 124, 4974-4975.

(24) Fukaya, Y.; Sugimoto, A.; Ohno, H. Superior solubility of polysaccharides in low viscosity, polar, and halogen-free 1,3-dialkylimidazolium formates. Biomacromolecules 2006, 7, 3295-3297.

(25) Fukaya, Y.; Hayashi, K.; Wada, M.; Ohno, H. Cellulose dissolution with polar ionic liquids under mild conditions: required factors for anions. Green Chem. 2008, 10, 4446.

(26) Fuller, J.; Carlin, R. T.; Osteryoung, R. A. The room temperature ionic liquid 1-ethyl-3-methylimidazolium tetrafluoroborate: electrochemical couples and physical properties. J. Electrochem. Soc. 1997, 144, 3881-3886.

(27) Hagiwara, R.; Hirashige, T.; Tsuda, T.; Ito, Y. Acidic 1-ethyl-3-methylimidazolium fluoride: a new room temperature ionic liquid. J. Fluorine Chem. 1999, 99, 1-3.

(28) Hagiwara, R.; Nohira, T.; Matsumoto, K.; Tamba, Y. A fluorohydrogenate ionic liquid fuel cell operating without humidification. Electrochem. Solid-State Lett. 2005, 8, A231-A233.

(29) Singh, M. P.; Singh, R. K.; Chandra, S. Ionic liquids confined in porous matrices: Physicochemical properties and applications. Prog. Mater. Sci. 2014, 64, 73-120.

(30) Lu, J.; Yan, F.; Texter, J. Advanced applications of ionic liquids in polymer science. Prog. Polym. Sci. 2009, 34, 431-448.

(31) Kitazawa, Y.; Ueno, K.; Watanabe, M. Advanced Materials Based on Polymers and Ionic Liquids. Chem. Rec. 2018, 18, 391-409.

(32) Mecerreyes, D. Polymeric ionic liquids: Broadening the properties and applications of polyelectrolytes. Prog. Polym. Sci. 2011, 36, 1629-1648.

(33) Green, O.; Grubjesic, S.; Lee, S.; Firestone, M. A. The design of polymeric ionic liquids for the preparation of functional materials. Polym. Rev. 2009, 49, 339-360.

(34) Dai, S.; Ju, Y. H.; Gao, H. J.; Lin, J. S.; Pennycook, S. J.; Barnes, C. E. Preparation of silica aerogel using ionic liquids as solvents. Chem. Commun. 2000, 243-244.

(35) Parnham, E. R.; Morris, R. E. Ionothermal synthesis of zeolites, metal-organic 
frameworks, and inorganic-organic hybrids. Acc. Chem. Res. 2007, 40, 1005-1013.

(36) Morris, R. E. Ionothermal synthesis -ionic liquids as functional solvents in the preparation of crystalline materials. Chem. Commun. 2009, 2990-2998.

(37) Singh, A.; Vedarajan, R.; Matsumi, N. Modified Metal Organic Frameworks (MOFs)/Ionic Liquid Matrices for Efficient Charge Storage. J. Electrochem. Soc. 2017, 164, H5169-H5174.

(38) Fujie, K.; Kitagawa, H. Ionic liquid transported into metal-organic frameworks. Coord. Chem. Rev. 2016, 307, 382-390.

(39) Cota, I.; Martinez, F. F. Recent advances in the synthesis and applications of metal organic frameworks doped with ionic liquids for $\mathrm{CO}_{2}$ adsorption. Coord. Chem. Rev. 2017, 351, 189-204.

(40) Kinik, F. P.; Uzun, A.; Keskin, S. Ionic Liquid/Metal-Organic Framework Composites: From Synthesis to Applications. ChemSusChem 2017, 10, 2842-2863.

(41) Zhang, S.; Zhang, J.; Zhang, Y.; Deng, Y. Nanoconfined ionic liquids. Chem. Rev. 2017, 117, 6755-6833.

(42) Luo, Q.-X.; An, B.-W.; Ji, M.; Zhang, J. Hybridization of metal-organic frameworks and task-specific ionic liquids: fundamentals and challenges. Mater. Chem. Front 2018, 2, 219-234.

(43) Cooper, E. R.; Andrews, C. D.; Wheatley, P. S.; Webb, P. B.; Wormald, P.; Morris, R. E. Ionic liquids and eutectic mixtures as solvent and template in synthesis of zeolite analogues. Nature 2004, 430, 1012-1016.

(44) Parnham, E. R.; Morris, R. E. The ionothermal synthesis of cobalt aluminophosphate zeolite frameworks. J. Am. Chem. Soc. 2006, 128, 2204-2205.

(45) Dybtsev, D. N.; Chun, H.; Kim, K. Three-dimensional metal-organic framework with $(3,4)$-connected net, synthesized from an ionic liquid medium. Chem. Commun. 2004, 1594-1595.

(46) Chen, W. X.; Xu, H. R.; Zhuang, G. L.; Long, L. S.; Huang, R. B.; Zheng, L.S. Temperature-dependent conductivity of $\mathrm{Emim}^{+}\left(\mathrm{Emim}^{+}=\right.$ 1-ethyl-3-methylimidazolium) confined in channels of a metal-organic framework. Chem. Commun. 2011, 47, 11933-11935.

(47) Park, K. S.; Zheng, N.; Côté, A. P.; Choi, J. Y.; Huang, R.; Uribe-Romo, F. J.; Chae, H. K.; O'Keeffe, M.; Yaghi, O. M. Exceptional chemical and thermal stability of zeolitic imidazolate frameworks. Proc. Natl. Acad. Sci. U.S.A. 2006, 103, 10186-10191. (48) Ban, Y.; Li, Z.; Li, Y.; Peng, Y.; Jin, H.; Jiao, W.; Guo, A.; Wang, P.; Yang, Q.; Zhong, C.; Yang, W. Confinement of Ionic Liquids in Nanocages: Tailoring the Molecular Sieving Properties of ZIF-8 for Membrane-Based $\mathrm{CO}_{2}$ Capture. Angew. 
Chem. Int. Ed. 2015, 54, 15483-15487.

(49) Kitagawa, S.; Kitaura, R.; Noro, S. Functional Porous Coordination Polymers. Angew. Chem. Int. Ed. 2004, 43, 2334-2375.

(50) Yamada, T.; Otsubo, K.; Makiura, R.; Kitagawa, H. Designer coordination polymers: dimensional crossover architectures and proton conduction. Chem. Soc. Rev. 2013, 42, 6655-6669.

(51) Ramaswamy, P.; Wong, N. E.; Shimizu, G. K. H. MOFs as proton conductorschallenges and opportunities. Chem. Soc. Rev. 2014, 43, 5913-5932.

(52) Sun, L.; Campbell, M. G.; Dincă, M. Electrically conductive porous metal-organic frameworks. Angew. Chem. Int. Ed. 2016, 55, 2-16.

(53) Bai, Y.; Dou, Y.; Xie, L.-H.; Rutledge, W.; Li, J.-R.; Zhou, H.-C. Zr-based metal-organic frameworks: design, synthesis, structure, and applications. Chem. Soc. Rev. 2016, 45, 2327-2367.

(54) Chen, Y.; Hu, Z.; Gupta, K. M.; Jiang, J. Ionic Liquid/Metal-Organic Framework Composite for $\mathrm{CO}_{2}$ Capture: A Computational Investigation. J. Phys. Chem. C 2011, $115,21736-21742$.

(55) Gupta, K. M.; Chen, Y. F.; Hu, Z. Q.; Jiang, J. W. Metal-organic Framework Supported Ionic Liquid Membranes for $\mathrm{CO}_{2}$ Capture: Anion Effects. Phys. Chem. Chem. Phys. 2012, 14, 5785-5794.

(56) Gupta, K. M.; Chen, Y. F.; Jiang, J. W. Ionic Liquid Membranes Supported by Hydrophobic and Hydrophilic Metal-Organic Frameworks for $\mathrm{CO}_{2}$ Capture. J. Phys. Chem. C 2013, 117, 5792-5799.

(57) Li, Z.; Xiao, Y.; Xue, W.; Yang, Q.; Zhong, C. Ionic Liquid/Metal-Organic Framework Composites for $\mathrm{H}_{2} \mathrm{~S}$ Removal from Natural Gas: A Computational Exploration. J. Phys. Chem. C 2015, 119, 3674-3683.

(58) Li, H.; Eddaoudi, M.; O'Keeffe, M.; Yaghi, O. M. Design and synthesis of an exceptionally stable and highly porous metal-organic framework. Nature 1999, 402, 276-279.

(59) Tsuzuki, S.; Tokuda, H.; Hayamizu, K.; Watanabe, M. Magnitude and directionality of interaction in ion pairs of ionic liquids: Relationship with ionic conductivity. J. Phys. Chem. B 2005, 109, 16474-16481.

(60) Walden, P. Organic solvents and Ionization Media. III. Interior Friction and its Relation to Conductivity. Z. Phys. Chem. 1906, 55, 207-249.

(61) $\mathrm{Xu}, \mathrm{W}$. ; Angell, C. A. Solvent-free electrolytes with aqueous solution-like conductivities. Science 2003, 302, 422-425.

(62) Ueno, K.; Tokuda, H.; Watanabe, M. Ionicity in ionic liquids: correlation with ionic 
structure and physicochemical properties. Phys. Chem. Chem. Phys. 2010, 12, 16491658 .

(63) Robeson, L. M. The upper bound revisited. J. Membr. Sci. 2008, 320, 390-400.

(64) Coasne, B.; Viau, L.; Vioux, A. Loading-Controlled Stiffening in Nanoconfined Ionic Liquids. J. Phys. Chem. Lett. 2011, 2, 1150-1154.

(65) Ori, G.; Villemot, F.; Viau, L.; Vioux, A.; Coasne, B. Ionic liquid confined in silica nanopores: molecular dynamics in the isobaric-isothermal ensemble. Mol. Phys. 2014, $112,1350-1361$.

(66) Tokuda, H.; Hayamizu, K.; Ishii, K.; Susan, M. A. B. H.; Watanabe, M. Physicochemical properties and structures of room temperature ionic liquids. 1. Variation of anionic species. J. Phys. Chem. B 2004, 108, 16593-16600.

(67) Umecky, T.; Saito, Y.; Matsumoto, H. Direct Measurements of Ionic Mobility of Ionic Liquids Using the Electric Field Applying Pulsed Gradient Spin-Echo NMR. $J$. Phys. Chem. B 2009, 113, 8466-8468.

(68) Umecky, T.; Kanakubo, M.; Ikushima, Y. Self-diffusion coefficients of 1-butyl-3-methylimidazolium hexafluorophosphate with pulsed-field gradient spin-echo NMR technique. Fluid Phase Equilib. 2005, 228, 329-333.

(69) Morris, W.; Volosskiy, B.; Demir, S.; Gándara, F.; McGrier, P. L.; Furukawa, H.; Cascio, D.; Stoddart, J. F.; Yaghi, O. M. Synthesis, structure, and metalation of two new highly porous zirconium metal-organic frameworks. Inorg. Chem. 2012, 51, 6443-6445.

(70) Wang, Z.; Tan, R.; Wang, H.; Yang, L.; Hu, J.; Chen, H.; Pan, F. A Metal-OrganicFramework-Based Electrolyte with Nanowetted Interfaces for High-Energy-Density Solid-State Lithium Battery. Adv. Mater. 2018, 30, 1704436/1-7.

(71) Cavka, J. H.; Jakobsen, S.; Olsbye, U.; Guillou, N.; Lamberti, C.; Bordiga, S.; Lillerud, K. P. A new zirconium inorganic building brick forming metal organic frameworks with exceptional stability. J. Am. Chem. Soc. 2008, 130, 13850-13851.

(72) Latroche, M.; Surblé, S.; Serre, C.; Mellot-Draznieks, C.; Llewellyn, P. L.; Lee, J. H.; Chang, J.-S.; Jhung, S. H.; Férey, G. Hydrogen storage in the giant-pore metal-organic frameworks MIL-100 and MIL-101. Angew. Chem. 2006, 118, 8407-8411.

(73) Fujie, K.; Yamada, T.; Ikeda, R.; Kitagawa, H. Introduction of an Ionic Liquid into the Micropores of a Metal-Organic Framework and Its Anomalous Phase Behavior. Angew. Chem. Int. Ed. 2014, 53, 11302-11305.

(74) Fujie, K.; Otsubo, K.; Ikeda, R.; Yamada, T.; Kitagawa, H. Low temperature ionic conductor: ionic liquid incorporated within a metal-organic framework. Chem. Sci. 2015, 
6, 4306-4310.

(75) Liu, C.; Feng, S.; Zhuang, Z.; Qi, D.; Li, G.; Zhao, C.; Li, X.; Na, H. Towards basic ionic liquid-based hybrid membranes as hydroxide-conducting electrolytes under low humidity conditions. Chem. Commun. 2015, 51, 12629-12632.

(76) Fujie, K.; Ikeda, R.; Otsubo, K.; Yamada, T.; Kitagawa, H. Lithium ion diffusion in a metal-organic framework mediated by an ionic liquid. Chem. Mater. 2015, 27, 73557361.

(77) Lassègues, J.-C.; Grondin, J.; Talaga, D. Lithium solvation in bis(trifluoromethanesulfonyl)imide-based ionic liquids, Phys. Chem. Chem. Phys. 2006, $8,5629-5632$.

(78) Umebayashi, Y.; Mitsugi, T.; Fukuda, S.; Fujimori, T.; Fujii, K.; Kanzaki, R.; Takeuchi, M.; Ishiguro, S. I. Lithium ion solvation in room-temperature ionic liquids involving bis(trifluoromethanesulfonyl)imide anion studied by Raman spectroscopy and DFT calculations. J. Phys. Chem. B 2007, 111, 13028-13032.

(79) Chen, L.-H.; Wu, B.-B.; Zhao, H.-X.; Long, L.-S.; Zheng, L.-S. High temperature ionic conduction mediated by ionic liquid incorporated within the metal-organic framework UiO-67 (Zr). Inorg. Chem. Commun. 2017, 81, 1-4.

(80) Wang, Z.; Wang, Z.; Yang, L.; Wang, H.; Song, Y.; Han, L.; Yang, K.; Hu, J.; Chen, H.; Pan, F. Boosting interfacial $\mathrm{Li}^{+}$transport with a MOF-based ionic conductor for solid-state batteries. Nano Energy 2018, 49, 580-587.

(81) Ponomareva, V. G.; Kovalenko, K. A.; Chupakhin, A. P.; Dybtsev, D. N.; Shutova, E. S.; Fedin, V. P. Imparting high proton conductivity to a metal-organic framework material by controlled acid impregnation. J. Am. Chem. Soc. 2012, 134, 15640-15643.

(82) Alberti, G.; Casciola, M. Solid state protonic conductors, present main applications and future prospects. Solid State Ionics 2001, 145, 3-16.

(83) Colomban, P., Ed. Proton Conductors: Solids, Membranes and Gels -Materials and Devices; Cambridge University Press: Cambridge, 1992.

(84) Dybtsev, D. N.; Ponomareva, V. G.; Aliev, S. B.; Chupakhin, A. P.; Gallyamov, M. R.; Moroz, N. K.; Kolesov, B. A.; Kovalenko, K. A.; Shutova, E. S.; Fedin, V. P. High Proton Conductivity and Spectroscopic Investigations of Metal-Organic Framework Materials Impregnated by Strong Acids. ACS Appl. Mater. Interfaces 2014, 6, 51615167.

(85) Sun, X.-L.; Deng, W.-H.; Chen, H.; Han, H.-L.; Taylor, J. M.; Wan, C.-Q.; Xu, G. A Metal-Organic Framework Impregnated with a Binary Ionic Liquid for Safe Proton Conduction above $100{ }^{\circ} \mathrm{C}$. Chem. Eur. J. 2017, 23, 1248-1252.

(86) Chen, H.; Han, S.-Y.; Liu, R.-H.; Chen, T.-F.; Bi, K.-L.; Liang, J.-B.; Deng, Y.-H.; 
Wan, C.-Q. High conductive, long-term durable, anhydrous proton conductive solid-state electrolyte based on a metal-organic framework impregnated with binary ionic liquids: Synthesis, characteristic and effect of anion. J. Power Sources 2018, 376, $168-176$.

(87) Li, Z.; Zhang, Z.; Ye, Y.; Cai, K.; Du, F.; Zeng, H.; Tao, J.; Lin, Q.; Zheng, Y.; Xiang, S. Rationally tuning host-guest interactions to free hydroxide ions within intertrimerically cuprophilic metal-organic frameworks for high $\mathrm{OH}^{-}$conductivity. $J$. Mater. Chem. A 2017, 5, 7816-7824.

(88) Varcoe, J. R.; Atanassov, P.; Dekel, D. R.; Herring, A. M.; Hickner, M. A.; Kohl, P. A.; Kucernak, A. R.; Mustain, W. E.; Nijmeijer, K.; Scott, K.; Xu, T.; Zhuang, L. Anion-exchange membranes in electrochemical energy systems. Energy Environ. Sci. 2014, 7, 3135-3191.

(89) Dutta, R.; Kumar, A. Structural and Dielectric Properties of Ionic Liquid Doped Metal Organic Framework based Polymer Electrolyte Nanocomposites. J. Phys.: Conf. Ser. 2016, 765, 012020/1-7.

(90) Li, Z.; Wang, W.; Chen, Y.; Xiong, C.; He, G.; Cao, Y.; Wu, H.; Guiver, M. D.; Jiang, Z. Constructing efficient ion nanochannels in alkaline anion exchange membranes by the in situ assembly of a poly(ionic liquid) in metal-organic frameworks. J. Mater. Chem. A 2016, 4, 2340-2348.

(91) Chui, S. S.-Y.; Lo, S. M.-F.; Charmant, J. P.; Orpen, A. G.; Williams, I. D. A chemically functionalizable nanoporous material $\left[\mathrm{Cu}_{3}(\mathrm{TMA})_{2}\left(\mathrm{H}_{2} \mathrm{O}\right)_{3}\right]_{n}$. Science 199, $283,1148-1150$.

(92) Tokuda, H.; Hayamizu, K.; Ishii, K.; Susan, M. A. B. H.; Watanabe, M. Physicochemical properties and structures of room temperature ionic liquids. 2. Variation of alkyl chain length in imidazolium cation. J. Phys. Chem. B 2005, 109, 6103-6110.

(93) Yoshida, Y.; Saito, G. Influence of structural variations in 1-alkyl-3-methylimidazolium cation and tetrahalogenoferrate(III) anion on the physical properties of the paramagnetic ionic liquids. J. Mater. Chem. 2006, 16, 1254-1262.

(94) Yoshida, Y.; Baba, O.; Saito, G. Ionic liquids based on dicyanamide anion: influence of structural variations in cationic structures on ionic conductivity. J. Phys. Chem. B 2007, 111, 4742-4749.

(95) Zhou, Z. B.; Matsumoto, H.; Tatsumi, K. Structure and properties of new ionic liquids based on alkyl- and alkenyltrifluoroborates. ChemPhysChem 2005, 6, 13241332.

Yoshida, Y.; Saito, G. Ionic liquids based on 
diethylmethyl(2-methoxyethyl)ammonium

cations

and

bis(perfluoroalkanesulfonyl)amide anions: influence of anion structure on liquid properties. Phys. Chem. Chem. Phys. 2011, 13, 20302-20310.

(97) Angell, C. A.; Byrne, N.; Belieres, J. P. Parallel developments in aprotic and protic ionic liquids: Physical chemistry and applications. Acc. Chem. Res. 2007, 40, 12281236.

(98) Greaves, T. L.; Drummond, C. J. Protic ionic liquids: evolving structure-property relationships and expanding applications. Chem. Rev. 2015, 115, 11379-11448.

(99) Amarasekara, A. S. Acidic Ionic Liquids. Chem. Rev. 2016, 116, 6133-6183.

(100) Yoshizawa, M.; Xu, W.; Angell, C. A. Ionic liquids by proton transfer: Vapor pressure, conductivity, and the relevance of $\Delta \mathrm{p} K_{\mathrm{a}}$ from aqueous solutions. J. Am. Chem. Soc. 2003, 125, 15411-15419.

(101) Kreuer, K. D.; Fuchs, A.; Ise, M.; Spaeth, M.; Maier, J. Imidazole and pyrazole-based proton conducting polymers and liquids. Electrochim. Acta 1998, 43, 1281-1288.

(102) Noda, A.; Susan, M. A. B. H.; Kudo, K.; Mitsushima, S.; Hayamizu, K.; Watanabe, M. Brønsted acid-base ionic liquids as proton-conducting nonaqueous electrolytes. $J$. Phys. Chem. B 2003, 107, 4024-4033. 
Table 1. Synthetic methods and ion-conducting properties of IL@MOF hybrid composites ${ }^{a}$

\begin{tabular}{|c|c|c|c|c|c|c|}
\hline IL or acid & MOF & Synthetic method & Loading level $^{e}$ & $\sigma\left(\mathrm{S} \mathrm{cm}^{-1}\right)$ & $E_{\mathrm{a}}(\mathrm{eV})$ & ref \\
\hline (EMI)(TFSA) & ZIF-8 & Capillary action & $f=1$ & $\begin{array}{l}2.6 \times 10^{-5}\left(22^{\circ} \mathrm{C}\right) \\
1.2 \times 10^{-4}\left(68^{\circ} \mathrm{C}\right)\end{array}$ & $0.35^{j}$ & 74 \\
\hline $\mathrm{Li}_{0.2} \mathrm{EMI}_{0.8} \mathrm{TFSA}_{\mathrm{H}}$ & ZIF-8 & Capillary action & $f=1$ & $\begin{array}{l}4.4 \times 10^{-6}\left(22^{\circ} \mathrm{C}\right) \\
6.3 \times 10^{-5}\left(70^{\circ} \mathrm{C}\right)\end{array}$ & $0.59^{k}$ & 76 \\
\hline$(\mathrm{EMI}) \mathrm{Cl}$ & $\mathrm{UiO}-67(\mathrm{Cr})$ & Capillary action & {$[(\mathrm{EMI}) \mathrm{Cl}] /[\mathrm{UiO}-67(\mathrm{Cr})]=7.82$} & $\begin{array}{l}1.5 \times 10^{-4}\left(100^{\circ} \mathrm{C}\right) \\
1.7 \times 10^{-3}\left(200^{\circ} \mathrm{C}\right)\end{array}$ & 0.37 & 79 \\
\hline $\mathrm{Li}_{0.17} \mathrm{EMI}_{0.83} \mathrm{TFSA}$ & $\mathrm{UiO}-67(\mathrm{Cr})$ & Capillary action & $1.5 \mathrm{~mL} / 1 \mathrm{~g}$ & $3.1 \times 10^{-4}\left(30^{\circ} \mathrm{C}\right)$ & & 80 \\
\hline $\mathrm{Li}_{0.2} \mathrm{EMI}_{0.8} \mathrm{TFSA}$ & MOF-525(Cu) & Capillary action & $1.5 \mathrm{~mL} / 1.2 \mathrm{~g}$ & $\begin{array}{l}3.0 \times 10^{-4}\left(25^{\circ} \mathrm{C}\right) \\
4.9 \times 10^{-3}\left(100^{\circ} \mathrm{C}\right)\end{array}$ & & 70 \\
\hline $\mathrm{H}_{2} \mathrm{SO}_{4}$ & MIL-101(Cr) & Wet impregnation & $f \sim 0.7$ & $\begin{array}{l}4.0 \times 10^{-2}\left(\text { ca. } 50^{\circ} \mathrm{C}\right)^{f} \\
6.0 \times 10^{-2}\left(80^{\circ} \mathrm{C}\right)^{f} \\
1 \times 10^{-2}\left(150^{\circ} \mathrm{C}\right)^{f}\end{array}$ & & 81 \\
\hline $\mathrm{H}_{3} \mathrm{PO}_{4}$ & MIL-101(Cr) & Wet impregnation & $f \sim 0.8$ & $\begin{array}{l}2.5 \times 10^{-4}\left(\text { ca. } 50^{\circ} \mathrm{C}\right)^{f} \\
3 \times 10^{-3}\left(150^{\circ} \mathrm{C}\right)^{f}\end{array}$ & 0.25 & 81 \\
\hline TfOH & MIL-101(Cr) & Wet impregnation & {$[\mathrm{TfOH}] /[\mathrm{MIL}-101(\mathrm{Cr})]=6.7$} & $5 \times 10^{-2}\left(\text { ca. } 60^{\circ} \mathrm{C}\right)^{f}$ & 0.23 & 84 \\
\hline $\mathrm{TsOH}$ & MIL-101(Cr) & Wet impregnation & {$[\mathrm{TsOH}] /[\mathrm{MIL}-101(\mathrm{Cr})]=1.1$} & $<10^{-7}\left(>100^{\circ} \mathrm{C}\right)^{f}$ & 0.58 & 84 \\
\hline EIMS/HTFSA $(3: 2)$ & MIL-101(Cr) & Capillary action & $f=1$ & $2.0 \times 10^{-4}\left(140^{\circ} \mathrm{C}\right)$ & 0.76 & 85 \\
\hline EIMS/ $\mathrm{H}_{2} \mathrm{SO}_{4}(1: 1)$ & MIL-101(Cr) & Capillary action & $f=1$ & $\begin{array}{l}2.5 \times 10^{-4}\left(50^{\circ} \mathrm{C}\right) \\
1.9 \times 10^{-3}\left(150^{\circ} \mathrm{C}\right)\end{array}$ & 0.26 & 86 \\
\hline EIMS/MeSO 3 H $(1: 1)$ & MIL-101(Cr) & Capillary action & $f=1$ & $1.0 \times 10^{-4}\left(150^{\circ} \mathrm{C}\right)$ & 0.30 & 86 \\
\hline EIMS/TsOH (1:1) & MIL-101(Cr) & Capillary action & $f=1$ & $\begin{array}{l}7.7 \times 10^{-6}\left(50^{\circ} \mathrm{C}\right) \\
2.8 \times 10^{-5}\left(150^{\circ} \mathrm{C}\right)\end{array}$ & 0.42 & 86 \\
\hline Cholinium hydroxide & ZIF-8 & Ionothermal synthesis & & $4 \times 10^{-7}\left(25^{\circ} \mathrm{C}\right)^{g}$ & 0.55 & 75 \\
\hline$(\mathrm{EVI}) \mathrm{OH}$ & FJU-66 & Wet impregnation & & $\begin{array}{l}5.2 \times 10^{-2}\left(20^{\circ} \mathrm{C}\right)^{h} \\
9.1 \times 10^{-2}\left(85^{\circ} \mathrm{C}\right)^{h}\end{array}$ & 0.11 & 87 \\
\hline
\end{tabular}

\section{Dispersed in polymer}




\begin{tabular}{|c|c|c|c|c|c|}
\hline$(\mathrm{BMI}) \mathrm{Br}$ & MOF-199 & Capillary action ${ }^{b}$ & $f=0.5$ & $1.3 \times 10^{-3}(\mathrm{RT})$ & 89 \\
\hline PIL (anion: $\mathrm{OH}$ ) & MIL-101(Cr) & $\begin{array}{l}\text { (1) Stir in PIL precursor } \\
\text { (2) Heat at } 60^{\circ} \mathrm{C} \\
\text { for polymerization }{ }^{c}\end{array}$ & PIL/MIL-101 weight ratio $=0.324$ & $3.7 \times 10^{-2}\left(20^{\circ} \mathrm{C}\right)$ & 90 \\
\hline Cholinium hydroxide & ZIF-8 & Ionothermal synthesis ${ }^{d}$ & & $\begin{array}{l}1.1 \times 10^{-4}\left(25^{\circ} \mathrm{C}\right)^{i} \\
9.8 \times 10^{-4}\left(60^{\circ} \mathrm{C}\right)^{i}\end{array}$ & 75 \\
\hline
\end{tabular}

${ }^{a} \sigma$ : ionic conductivity, $E_{\mathrm{a}}$ : activation energy. ${ }^{b}$ Dispersed in poly(ethylene oxide). ${ }^{c}$ Dispersed in styrene-ethylene/butylene-styrene block copolymer. ${ }^{d}$ Dispersed in poly(vinyl alcohol). ${ }^{e} f$ : volumetric occupancy. ${ }^{f} 0.6$ mol\% water. ${ }^{g} 98 \%$ RH. ${ }^{h} 95 \%$ RH. ${ }^{i} 33 \%$ RH. ${ }^{j}$ Fitted between 5 and $68^{\circ} \mathrm{C}$. ${ }^{k}$ Fitted between 5 and $70{ }^{\circ} \mathrm{C}$. 
<smiles>[R2][n+]1ccccc1</smiles>

$\mathrm{N}$-alkylpyridinuim<smiles>[R5][N+]1([R5])CCCCC1</smiles>

$\mathrm{N}, \mathrm{N}$-dialkylpiperidinium

$\mathrm{R}_{2}$<smiles>[R][n+]1ccn(C)c1</smiles>

1-alkyl-3-methylimidazolium<smiles>[R][N+]1([R])CCCC1</smiles>

$N, N$-dialkylpyrrolidinium<smiles>C=Cc1ccc(Cn2cc[n+](C=C)c2)cc1</smiles>

1-ethenyl-3-[(4-ethenylphenyl)methyl]imidazolium

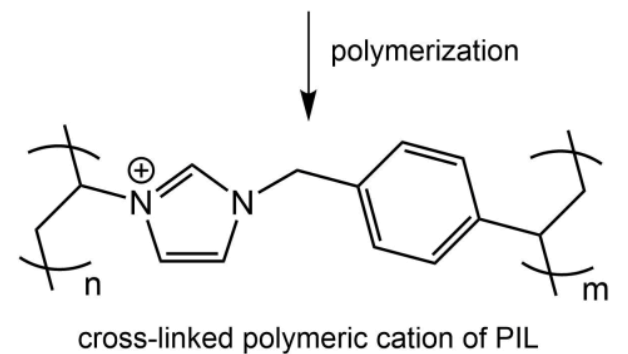

cross-linked polymeric cation of PIL<smiles>C=Cn1cc[n+](CC)c1</smiles><smiles>C[N+](C)(C)CCO</smiles>

1-ethyl-3-vinylimidazolium $(\mathrm{EVI})$

2-(hydroxyethyl)trimethylammonium (cholinium)

Figure 1. Organic cations presented in this review (DMI: $\mathrm{R}_{1}=$ methyl, EMI: $\mathrm{R}_{1}=$ ethyl, BMI: $\mathrm{R}_{1}=n$-butyl). 

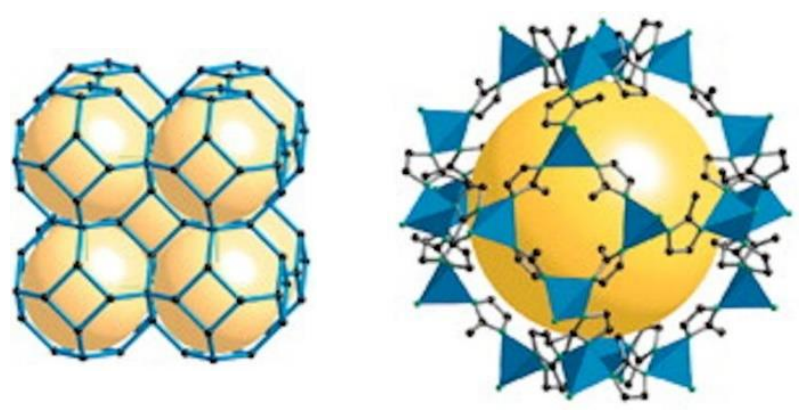

Figure 2. (Left) Crystal structure of ZIF-8, where blue sticks and yellow spheres represent the frameworks and pores, respectively. (Right) Framework structure surrounding a sphere, where blue tetrahedra represent $\mathrm{ZnN}_{4}$ units and hydrogen atoms are omitted for clarity. Adapted with permission from ref 47. Copyright 2006 National Academy of Sciences. 


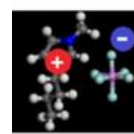

IL

(a)
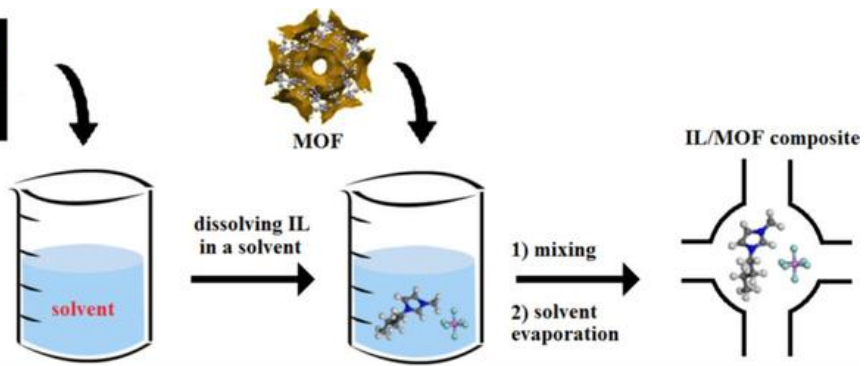

(b)

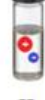

IL
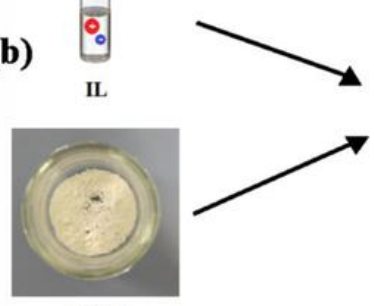

MOF

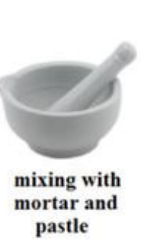

heating for better diffusion

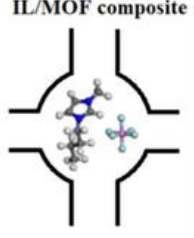

pastle
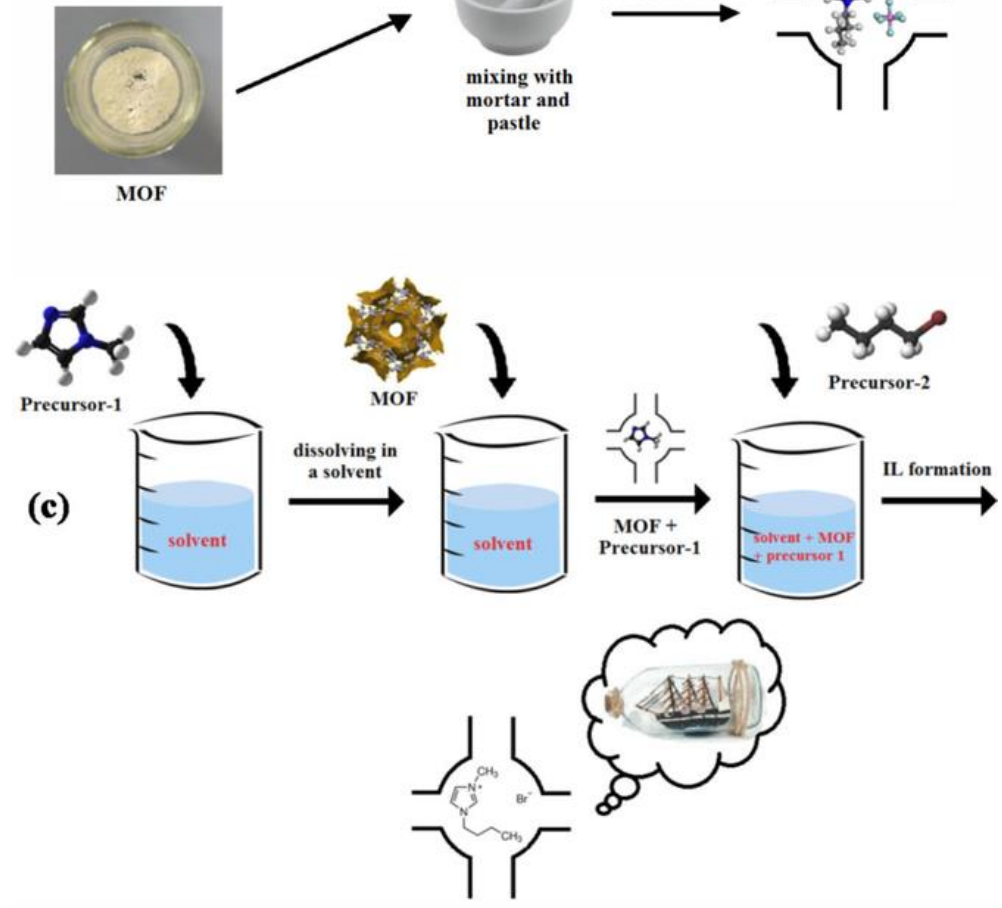

Figure 3. Representation of different post-impregnation methods used in the synthesis of IL@MOF hybrid composites: (a) Wet impregnation method, (b) capillary action method, and (c) ship-in-bottle (or tandem) method. Adapted with permission from ref 40. Copyright 2017 WileyVCH. 


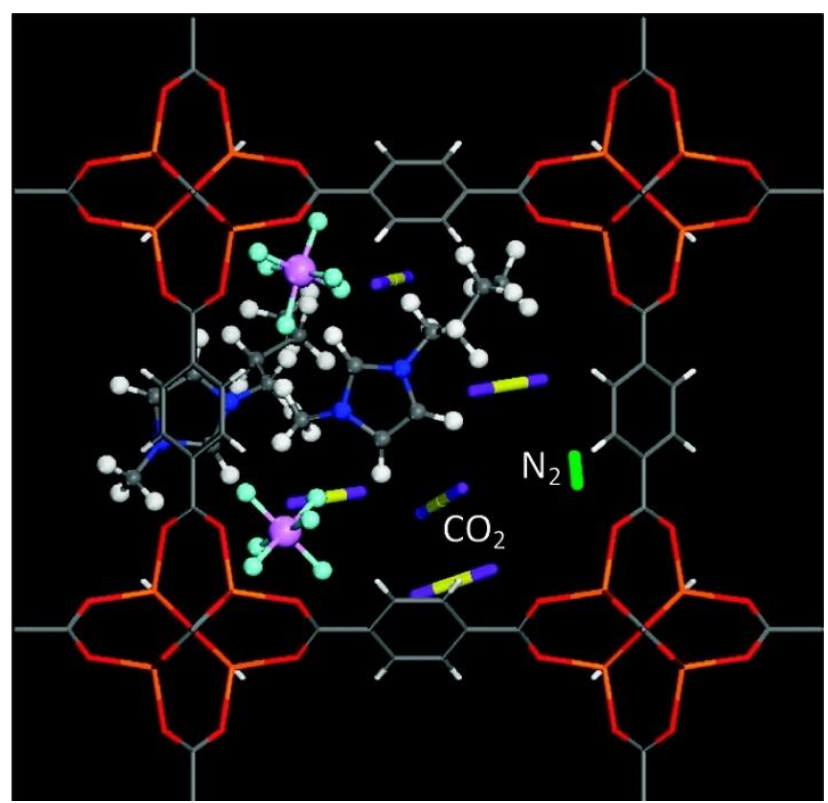

Figure 4. Simulation snapshot of $\mathrm{CO}_{2} / \mathrm{N}_{2}$ mixture in $(\mathrm{BMI})\left(\mathrm{PF}_{6}\right) @ \mathrm{MOF}-5$. Adapted with permission from ref 54. Copyright 2011 American Chemical Society. 


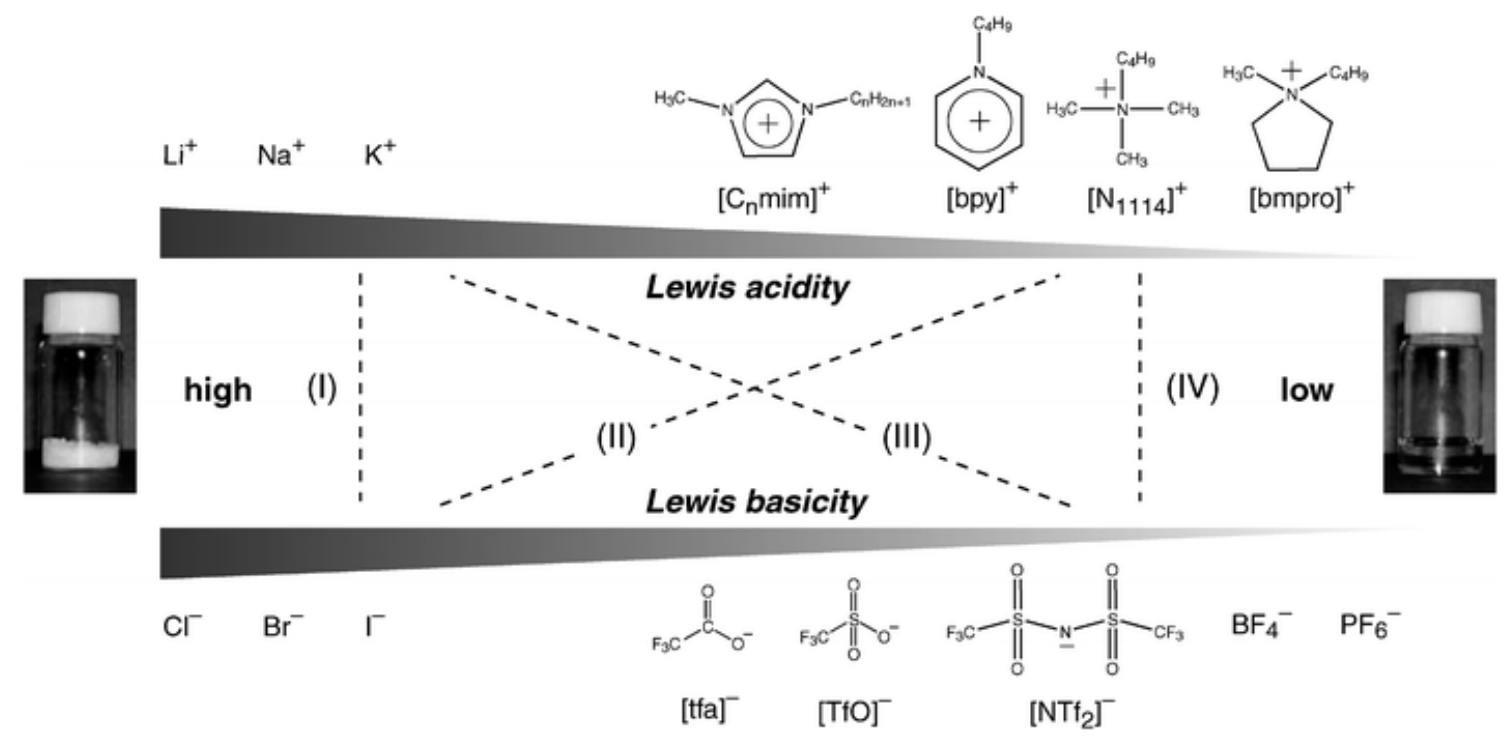

Figure 5. Various combinations of salts consisting of cations and anions, arranged in order of Lewis acidity for cations and Lewis basicity for anions. $\mathrm{C}_{\mathrm{n}} \mathrm{mim}$ : 1-alkyl-3-methylimidazolium, $\quad$ bpy: $\quad N$ - $n$-butylpyridinium, $\quad \mathrm{N}_{1114}$ : trimethyl- $n$-butylammonium, bmpro: $\quad N$ - $n$-butyl- $N$-methylpyrrolidinium, $\quad$ tfa: trifluoroacetate, $\quad$ TfO: trifluoromethanesulfonate, $\quad \mathrm{NTf}_{2}$ : bis(trifluoromethanesulfonyl)amide (TFSA). Combinations of types (I)-(III) afford high- $T_{\mathrm{m}}$ salts with strong interionic interactions, whereas a combination of type (IV) affords low- $T_{\mathrm{m}}$ salts with high degrees of ion dissociation. Adapted with permission from ref 62. Copyright 2010 Royal Society of Chemistry. 
a
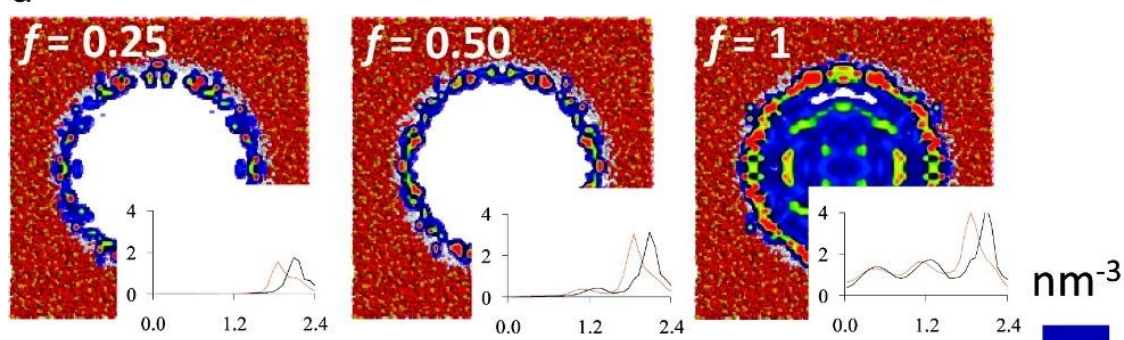

b
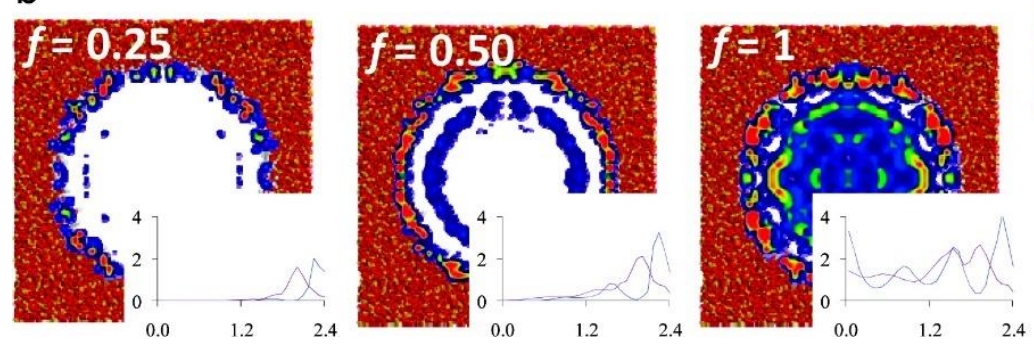

Figure 6. Contour plots showing the density distribution at RT of (a) TFSA anions and (b) BMI cations of (BMI)(TFSA) at location $(x, y)$ in a nanoporous hydroxylated silica with a diameter of $4.8 \mathrm{~nm}$. Filling fractions are (from left to right) $f=0.25,0.50$, and 1 . The scale is linear in local anion density in $\mathrm{nm}^{-3}$. The silica pore is also shown for the sake of clarity. Orange and red segments denote silicon and oxygen atoms, respectively, while the white segments are hydrogen atoms that delimit the pore surface. For each anion contour plot, the inset shows the radial density profiles in $\mathrm{nm}^{-3}$ for the fluorine (orange line) and oxygen (black line) atoms of the anion. For each cation contour plot, the inset shows the radial density profiles in $\mathrm{nm}^{-3}$ for the nitrogen atom (blue line) and the terminal carbon atom of the $n$-butyl chain (purple line) of the cation. Adapted with permission from ref 64. Copyright 2011 American Chemical Society. 


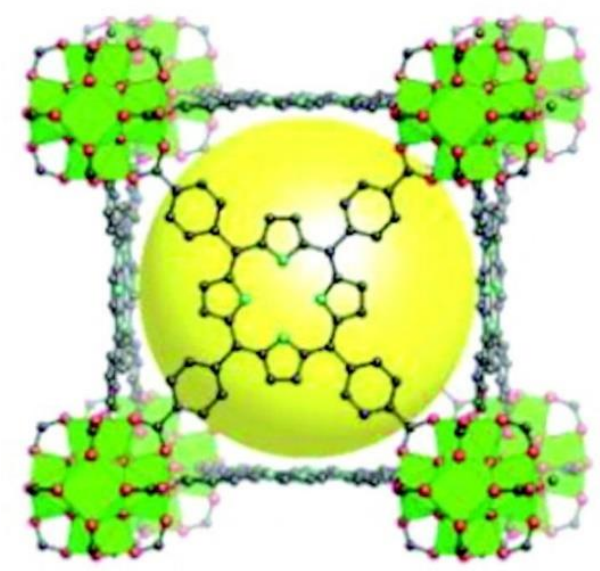

Figure 7. Crystal structure of MOF-525, where a pore in the framework is illustrated by a yellow sphere. Atom colors: green: Zr, black: C, dark green: N, red: O. Hydrogen atoms are omitted for clarity. Adapted with permission from ref 69. Copyright 2012 American Chemical Society. 


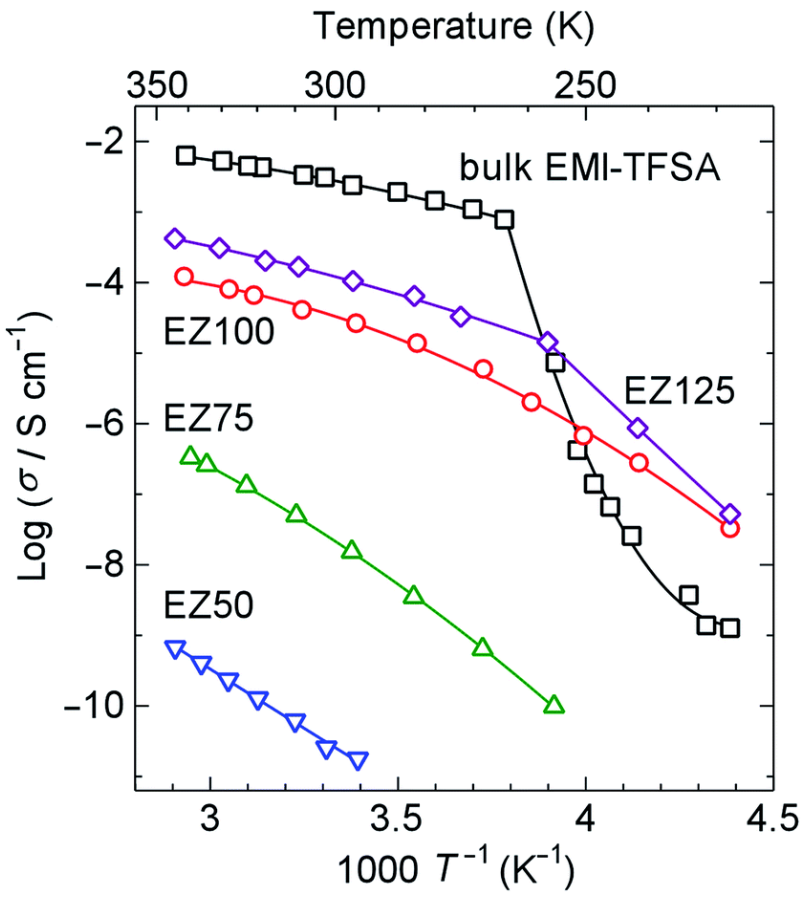

Figure 8. Arrhenius plots of the ionic conductivity $(\sigma)$ of (EMI)(TFSA)@ZIF-8 with $f$ $=0.5(\mathrm{EZ} 50), f=0.75$ (EZ75), $f=1$ (EZ100), and $f=1.25(\mathrm{EZ125})$, together with that of bulk (EMI)(TFSA). The solid lines are drawn as guides for the eye. Adapted with permission from ref 74. Copyright 2015 Royal Society of Chemistry. 


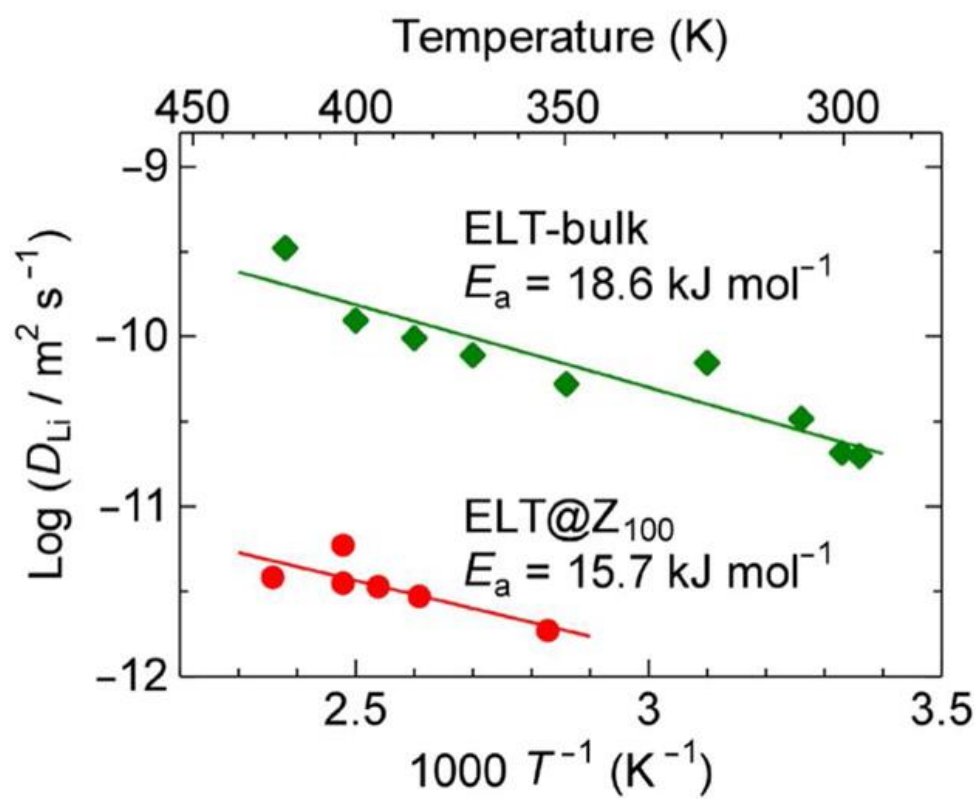

Figure 9. Arrhenius plots of the self-diffusion coefficient of the lithium nucleus $\left(D_{\mathrm{Li}}\right)$ in $\mathrm{Li}_{0.2} \mathrm{EMI}_{0.8}$ TFSA@ZIF-8 with $f=1$ (ELT@Z100) and bulk Li ${ }_{0.2} \mathrm{EMI}_{0.8}$ TFSA (ELT-bulk) measured by ${ }^{7} \mathrm{Li}$ pulsed-field gradient spin-echo NMR. Adapted with permission from ref 76. Copyright 2015 American Chemical Society. 

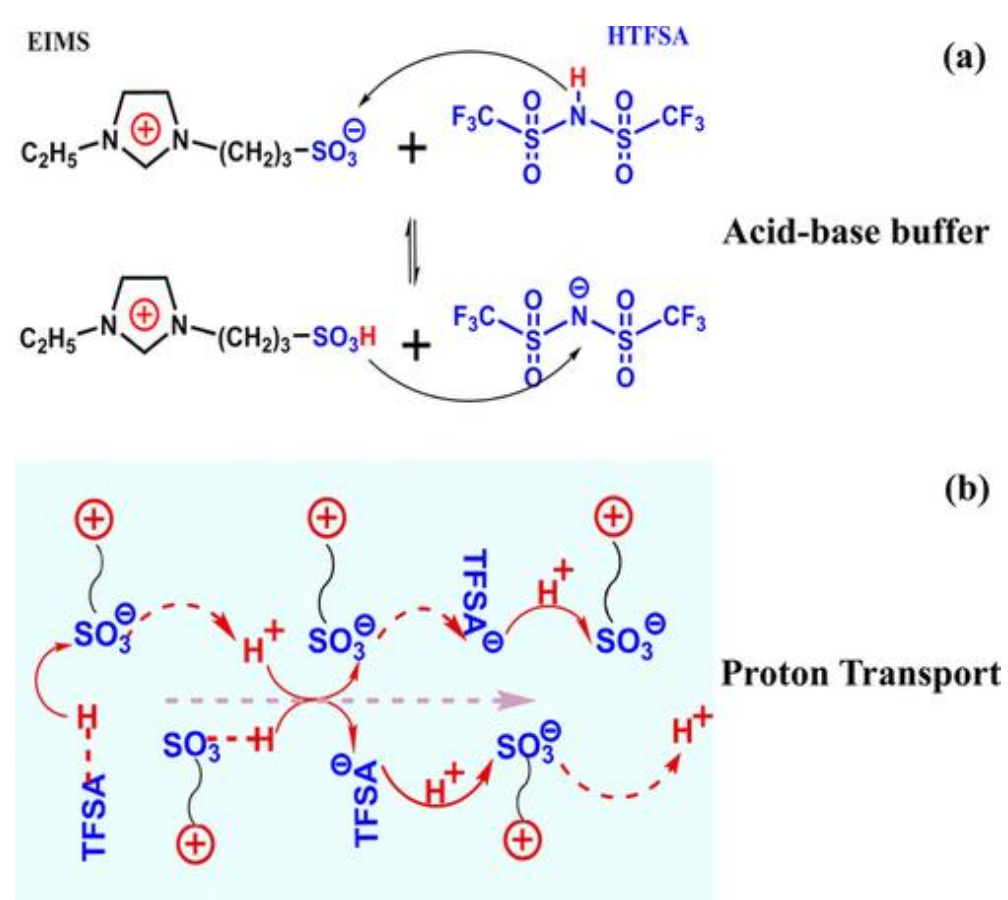

Figure 10. (a) Diagram of the binary IL, EIMS/HTFSA, and Brønsted acid-base buffer. (b) Illustration of proton hopping within the matrix of EIMS/HTFSA. Adapted with permission from ref 85. Copyright 2017 WileyVCH. 


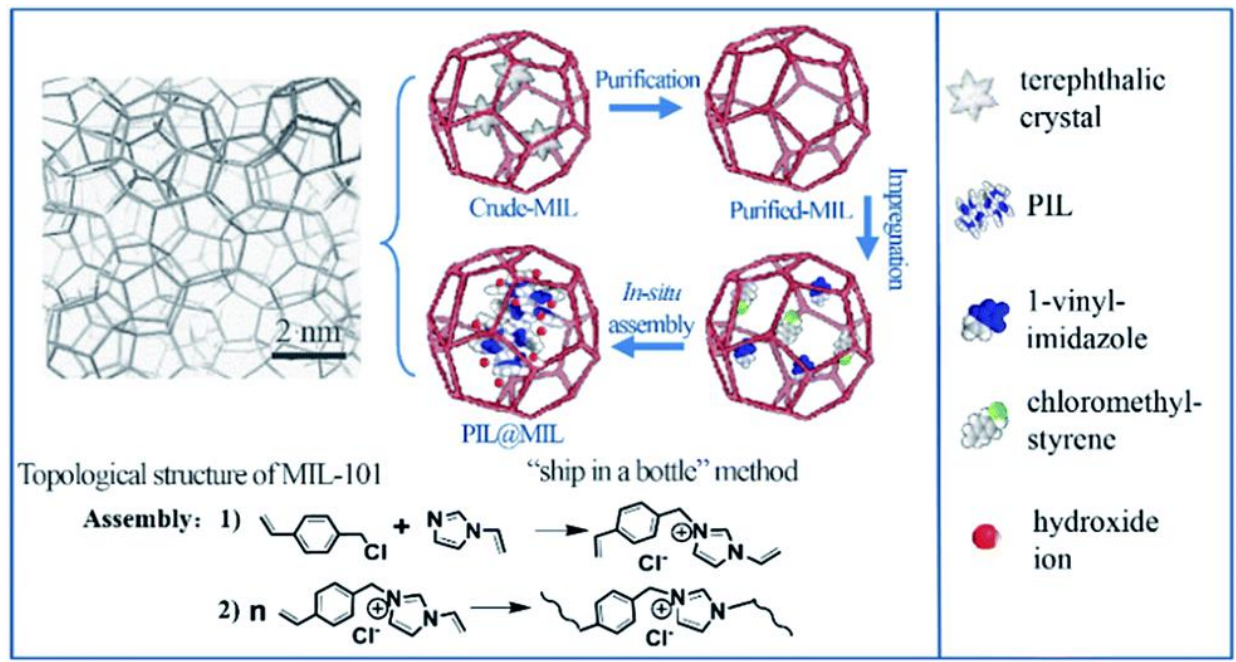

Figure 11. The in situ assembly of polymeric IL@MIL-101(Cr) via the ship-in-bottle method. Adapted with permission from ref 90. Copyright 2016 Royal Society of Chemistry. 


\section{For Table of Contents Use Only}

\section{TOC/Abstract Graphic:}

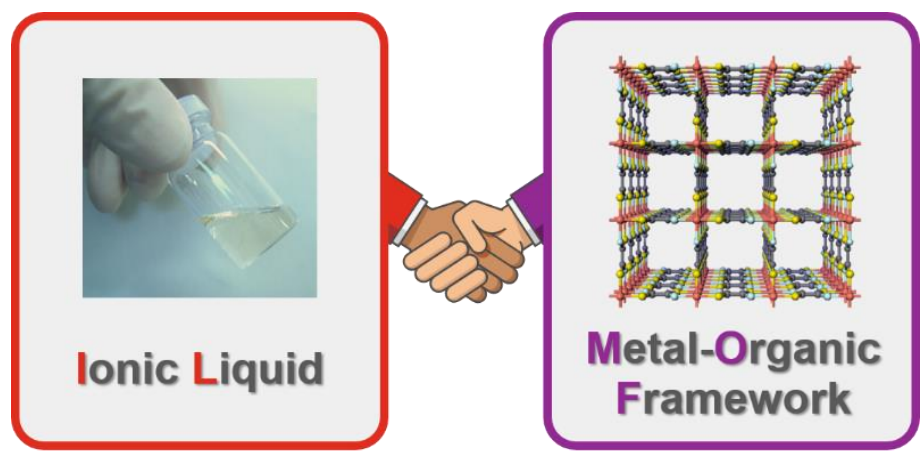

\section{Synopsis:}

Ion-conducting properties including proton and hydroxide conductions of metal-organic frameworks incorporating ionic liquids are reviewed. 


\section{Photographs and Biographies}

\section{Yukihiro Yoshida}

Yukihiro Yoshida was born in Okayama, Japan in 1973. He received his BSc degree from Okayama University in 1996 and PhD degree from Kyoto University in 2001. After postdoctoral research at Kyoto University and Université de Rennes 1, he moved to Meijo University as an assistant professor. In 2017, he moved back to Kyoto University and is currently an associate professor at the same university. His current research interests are functional metal complexes including metal-organic frameworks, organic superconductors, spin frustrated materials, supramolecular rotors, and ionic liquids.

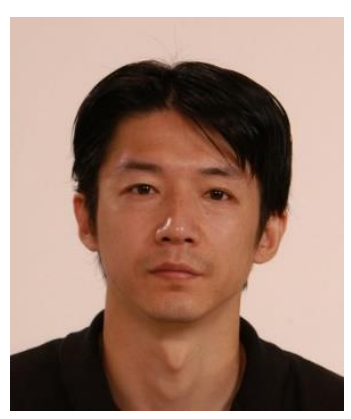

\section{Hiroshi Kitagawa}

Hiroshi Kitagawa, born in December 1961 in Osaka, finished his Ph.D. at Kyoto University in 1991 and, after working as Assistant Professor at IMS (Okazaki) and JAIST (Kanazawa), he was appointed as Associate Professor at the University of Tsukuba in 2000. He became Professor of Chemistry at Kyushu University in 2003 and was appointed to Kyoto University as Professor in 2009. He is now Vice Provost and Deputy Executive-Vice President for Research at Kyoto University. He is also engaged at Japan Science \& Technology Agency (JST) as a Research Director of "ACCEL" and a Director of a network-type research institution "Science and Creation of Innovative Catalysts, PRESTO". He has published more than 350 original papers on research dealing with solid-state chemistry, coordination chemistry, nano-science, low-dimensional electron system, and molecule-based conductor.

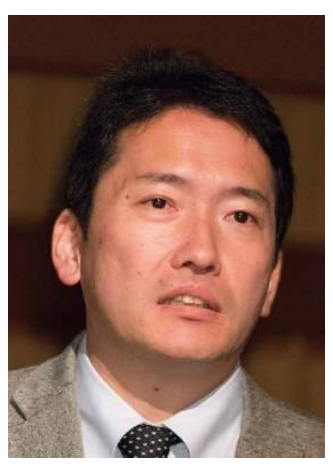

